\title{
SISTEMA DE ESPAÇOS LIVRES E ESPACIALIDADES DA ESFERA PÚBLICA EM FAVELA: OS CASOS DE PARAISÓPOLIS, DA LINHA E DO NOVE EM SÃO PAULO
}

\author{
OPEN SPACE SYSTEM AND PUBLIC DIMENSIONS OF SPACE IN THE FAVELA: \\ THE CASES OF PARAISÓPOLIS, LINHA AND NOVE, IN SÃO PAULO.
}

\section{Eduardo Pimentel Pizarro*}

\section{RESUMO}

As favelas são realidades consolidadas na cidade de São Paulo, concentrando mais de 10\% de sua população, e o Sistema de Espaços Livres da cidade dita informal constitui grande potencial de investigação no que diz respeito a suas características físicas, à articulação entre espaços públicos e privados e, principalmente, às práticas públicas e cotidianas nele desenvolvidas. No presente artigo, são selecionadas, como estudos de caso, três favelas da cidade de São Paulo: a favela de Paraisópolis - segunda maior comunidade do município, localizada em meio ao "Morumbi", com cerca de 100 mil habitantes em 100 hectares de área -, as favelas da Linha e do Nove, que juntas ocupam menos de 2 hectares no entorno da Companhia de Entrepostos e Armazéns Gerais de São Paulo (Ceagesp) e concentram 630 famílias. Baseado em visitas de campo, este artigo mostra quais as dinâmicas espaciais e públicas que regem esses espaços e que poderiam servir à discussão do Sistema de Espaços Livres da cidade.

Palavras-chave: Favela. Sistema de Espaços Livres. Esfera pública. Espacialidades da esfera pública.

\section{ABSTRACT}

The favelas constitute a consolidated reality in the city of São Paulo, concentrating more than 10\% of its total population. And the open space system inside the informal city represents great investigative potential in regard to its physical characteristics, to the articulation established between public and private spaces and, mostly, to the public and ordinary practices developed inside it. With this aim, the article selects three favelas in the city of São Paulo as case studies: the favela de Paraisópolis, the second biggest community in the municipality, which is located in the Morumbi neighbourhood with around 100.000 inhabitants in an area of 100 acres; the favela da Linha and the favela do Nove, which together occupy less than 2 acres in the General Stores Company of São Paulo (Ceagesp) neighborhood, concentrating 630 families. Based on fieldwork, the article shows how the spatial and public dynamics work in these spaces and how they could help us discuss the open space system of the whole city.

Keywords: Favela. Open Space System. Public sphere. Public dimensions of space.

Arquiteto e urbanista, mestre e doutorando em Arquitetura na Faculdade de Arquitetura e Urbanismo da Universidade de São Paulo (FAUUSP). Bolsista da Fundação de Amparo à Pesquisa do Estado de São Paulo (Fapesp). CV: http://lattes.cnpq.br/9455878151905548 


\section{INTRODUÇÃO}

O objeto analisado neste artigo é o Sistema de Espaços Livres (SEL) e respectivas espacialidades da esfera pública em três favelas da cidade de São Paulo: a favela de Paraisópolis, a favela da Linha e a favela do Nove. A escolha desses estudos de caso é pautada por critérios populacionais, dimensionais, fundiários e de inserção urbana, de modo a representar diferentes situações típicas de favelas consolidadas na cidade de São Paulo. Para a conceituação de SEL e espacialidades da esfera pública, toma-se, como principal referência, Queiroga $(2001,2006,2012)$ - devido à síntese que faz dos demais autores citados ao longo do artigo.

O objetivo deste artigo é analisar comparativamente os SELs das favelas selecionadas no que diz respeito a características físicas, à articulação entre o Sistema de Espaços Livres Públicos (SELP) e o conjunto de espaços livres privados, culminando na leitura das espacialidades da esfera pública em seus espaços públicos e privados. Busca-se, também, questionar o que são, efetivamente, espaços livres públicos e privados em favela, e como poderiam servir à discussão e proposição dos espaços livres da cidade como um todo.

O método de análise dos estudos de caso selecionados é basicamente empírico, sustentado por visitas de campo nas quais o desenho, o registro fotográfico e as conversas informais com a comunidade são as principais ferramentas de observação, transcrição e análise do objeto de estudo. Uma vez sistematizadas, e partindo de revisão bibliográfica, as informações de campo conduzem a uma discussão acerca dos SEL e respectivas espacialidades da esfera pública nas três favelas selecionadas.

\section{ESPAÇO, ESFERA E ESPACIALIDADE PÚBLICOS}

O presente artigo não pretende construir um estado da arte acerca dos conceitos de espaço livre. Com o simples objetivo de explicitar, de forma clara e objetiva, a partir de quais conceitos o artigo se desenvolve, são descritos os conceitos de: espaço livre e SEL, espaço e esfera públicos e espacialidades da esfera pública - ancorados principalmente nas definições de Queiroga.

Segundo Magnoli, espaço livre é o espaço livre de edificações, isto é, espaços abertos e não cobertos, como parques, praças, ruas, quintais, recuos, pátios, terrenos baldios. (MAGNOLI, 1982). De acordo com sua propriedade, o espaço livre pode

ser público ou privado. Espaço público, portanto, é aquele de propriedade pública, podendo ou não abrigar ações de esfera pública. Os bens públicos podem ser de uso comum do povo, ou seja, espaços a serem utilizados sem necessidade de autorização, como rios, estradas, ruas e praças; de uso especial, tais como edifícios ou terrenos a serviço de administrações governamentais; ou dominicais, que constituem patrimônio de pessoas jurídicas de direito público, em grande parte áreas com potencial de ocupação. (BRASIL, 2002, Art. 98).

O conjunto de espaços livres conforma um SEL: 
[...] independentemente de sua dimensão, de sua localização, qualificação estética, funcional e propriedade, sejam elas públicas ou privadas. A noção de SEL implica necessariamente relações de natureza funcional e socioambiental, tendo em vista que fisicamente nem todos os espaços livres estão conectados entre si. (QUEIROGA, 2012, p. 75).

SELP é o conjunto de espaços livres públicos. Em se tratando de espaços livres privados, a denominação aplicada é a de conjunto - e não sistema - de espaços livres privados.

Conceito diferente de espaço público, a esfera pública geral é composta por toda a vida em público e inclui a esfera pública política:

[...] o que pode ser visto e ouvido por todos, abrangendo a maior divulgação possível; o próprio mundo, na medida em que é comum a todos e diferente do lugar que nele nos cabe [...] reúne-nos na companhia dos outros e contudo evita que colidamos uns nos outros [...] (ARENDT, 1991, p. 59).

A esfera de vida cotidiana também se inclui no conceito de esfera pública geral:

[...] seja um passeio familiar num parque público aos fins de semana, o andar pela cidade após a jornada de trabalho, o encontro de jovens de uma 'tribo urbana' específica num cemitério paulistano ou portenho, o convívio público num botequim carioca, numa padaria paulistana ou num café parisiense. O convívio público, voluntário ou involuntário, possui um grau de civilidade que, em harmonia ou em conflito, já se constitui parte da vida pública, integrante da esfera pública geral [...] (QUEIROGA, 2012, p. 49).

Vista a separação conceitual entre espaço e esfera públicos, cabe o conceito de espacialidades da esfera pública (QUEIROGA, 2006), que são práticas espaciais da vida pública realizadas em espaços públicos ou privados:

[...] ainda que majoritariamente se deem nos espaços livres públicos, sobretudo nos bens de uso comum do povo, podem se realizar em diferentes espaços: livres ou edificados, públicos ou privados. A esfera pública geral, ou mesmo a esfera política, se efetiva, portanto, em um amplo sistema de espaços, com maior ou menor intensidade neste ou naquele lugar. (QUEIROGA, 2012, p. 59-60).

Várias são as situações de apropriação pública de espaços livres privados, desde a ocupação informal de terrenos baldios nas inúmeras periferias das cidades brasileiras com campinhos de futebol, até as 'praças corporativas' [...] Os recuos frontais nos lotes podem apresentar uma dimensão pública elementar, nem por isso menos importante, de permitir a visibilidade pública de jardins frontais e dos edifícios. Trata-se, na maioria das vezes, de acessibilidade visual e não física, mas revela relação de respeito do privado para com o público. (QUEIROGA, 2012, p. 125). 
Posto isso, qual a importância das espacialidades da esfera pública? Quais as suas especificidades e seus principais campos de ação nas favelas? Em que medida tais conceitos se adequam à lógica informal do SEL das favelas paulistanas? Com esses conceitos e questionamentos em mente, o presente artigo prossegue.

\section{FAVELAS EM SÃO PAULO: PARAISÓPOLIS, DA LINHA E DO NOVE}

Nas décadas de 1960 e 1970, as favelas eram, predominantemente, construídas em madeira, com materiais precários e provisórios. A partir da década de 1980, com o início da instalação de serviços como energia elétrica, água e esgoto, o poder público acaba, em certa medida, legitimando esse tipo de ocupação urbana dita informal, reduzindo o sentimento de insegurança, o tal "medo da remoção", intrínseco a essa população. A partir daí, a comunidade estabelece com o seu meio uma nova relação, de maior identidade e permanência, de consolidação.

Os barracos, antes de madeira, são gradativamente reconstruídos em alvenaria (figura 1), muitas vezes revestidos com argamassa e pintura nas paredes, cerâmica no chão, além de concentrarem bens de consumo iguais ou semelhantes aos comumente acumulados pela classe média brasileira.

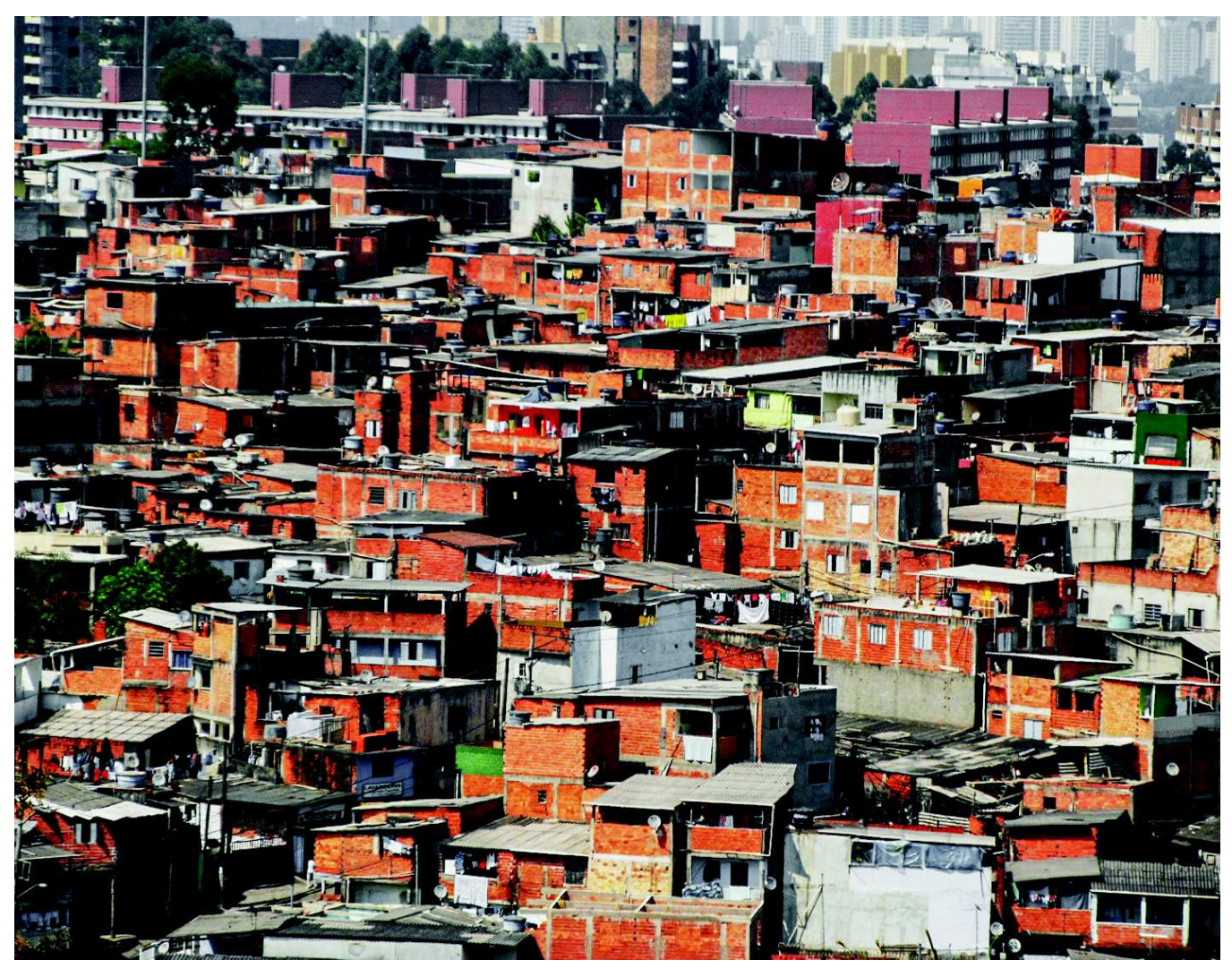

Figura 1 Visão geral da favela de Paraisópolis.

Foto: Eduardo Pimentel Pizarro, 2012. 
Na favela, o elevado nível de consolidação e permanência não pode ser confundido com rigidez e estanqueidade. Pelo contrário, a favela é reconhecida pelo seu constante processo de construção e reconstrução, em escalas urbana e edilícia. As figuras 2 e 3 evidenciam, de forma típica, o processo dinâmico de constituição da favela, onde a ocupação começa junto a infraestruturas urbanas existentes, como sistema viário, por exemplo, e se expande em direção ao terreno desocupado - de forma mais orgânica e espontânea - por meio de vielas e becos. Uma mesma edificação se verticaliza à medida que a família aumenta de tamanho ou, até mesmo, quando passa a abrigar outras famílias (que podem alugar ou comprar um pavimento da construção) e outros usos (como uma padaria ou salão de cabeleireiros no térreo, ou a laje para fazer churrasco e estender roupas no último pavimento).

Mundialmente, dos 7 bilhões de habitantes (Organização das Nações Unidas [ONU], 2011), cerca da metade reside em meio urbano. (ONU, 2000). Dessa população urbana, 29\% (DAVIS, 2007) - cerca de 1 bilhão de pessoas - concentra-se em assentamentos irregulares e desprovidos de condições mínimas de salubridade, saneamento e serviços.

O Brasil, com mais de 190 milhões de habitantes, dos quais $84,4 \%$ habitam áreas urbanas, possui 11.425.644 milhões de habitantes em assentamentos informais, montante equivalente a $6 \%$ da população nacional e à população total absoluta do município de São Paulo (11.253.503 milhões), a sétima cidade mais populosa do mundo e a mais populosa d as Américas. (Instituto Brasileiro de Geografia e Estatística [IBGE], 2010).

Dos 11 milhões de paulistanos, 3,3 milhões habitam assentamentos precários (30\% da população) - dos quais 1,6 milhões moram em favelas, em quase 400 mil habitações (Secretaria de Habitação [Sehab], 2010) com condições precárias de insolação, ventilação, carência de serviços e equipamentos públicos. De acordo com o Censo de 2010 (IBGE), a população absoluta de favelados no município de São Paulo é de 1.280.400 milhão, em 355.756 mil domicílios, dos quais 232.255 mil possuem dois pavimentos e 299.744 mil não possuem mínimo espaçamento entre si. (IBGE, 2010). As favelas constituem, de fato, uma realidade consolidada no meio urbano paulistano. (PIZARRO, 2014).

Apesar de classificadas pela denominação comum de "favela", cada qual varia de acordo com histórico de ocupação, inserção urbana, propriedade fundiária, escalas territorial e populacional, níveis de consolidação e precariedade e possíveis investimentos públicos e/ou projetos de intervenção urbana e habitacional.

Para o presente artigo, são selecionadas como estudo de caso três favelas localizadas em áreas consolidadas da cidade de São Paulo (figura 4), escolhidas por possuírem propriedades fundiárias, escalas territorial e populacional diferentes: a favela de Paraisópolis, a favela da Linha e a favela do Nove.

A favela de Paraisópolis (figura 5), cuja ocupação é iniciada na década de 1950, estende-se por uma área entre 80 e 100 hectares de propriedade particular no distrito Vila Andrade, zona sul de São Paulo. Popularmente, é considerada parte do Morumbi, bairro de renda média alta da cidade. A população estimada da favela era de 43 mil habitantes em 2010 (IBGE, 2010), 55 mil em 2011 (SEHAB, 2011) e 100 mil em 2014 

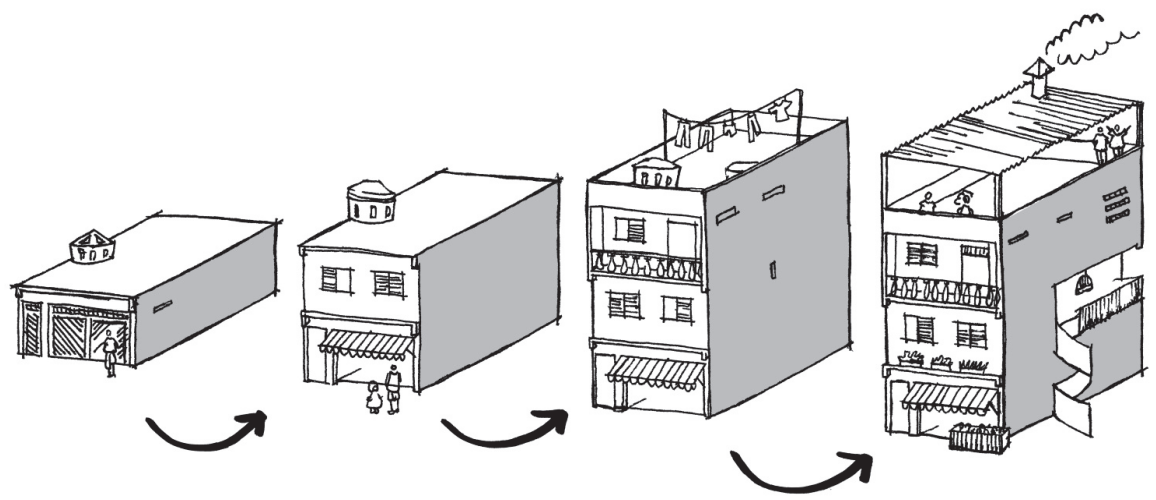

Figura 2 Processo de verticalização edilícia. Desenho: Eduardo Pimentel Pizarro, 2016.
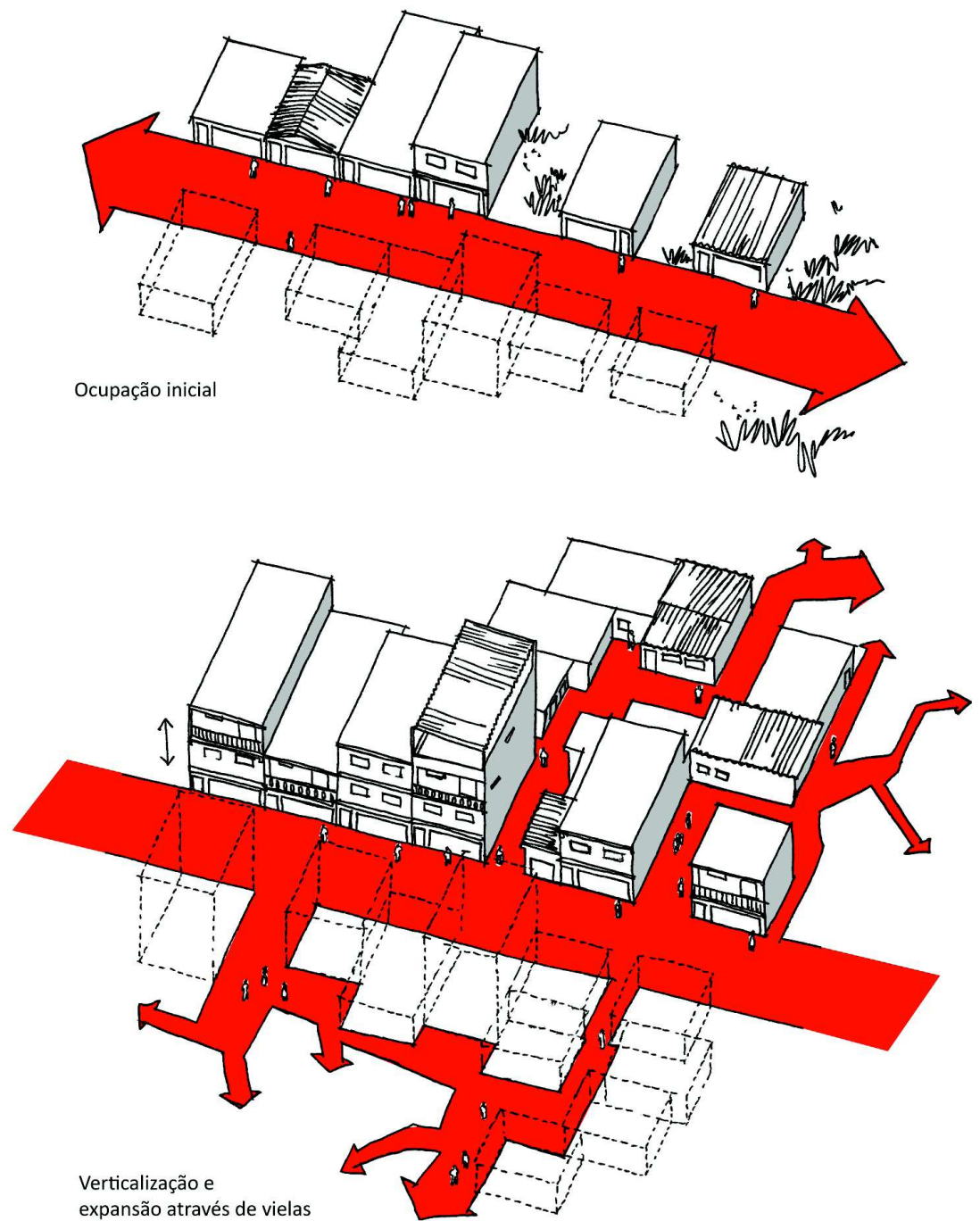

Figura 3 Processo de constituição urbana da favela, tipicamente a partir da proximidade de uma infraestrutura existente e, posteriormente, expansão por vielas e verticalização.

Desenho: Eduardo Pimentel Pizarro, 2016. 


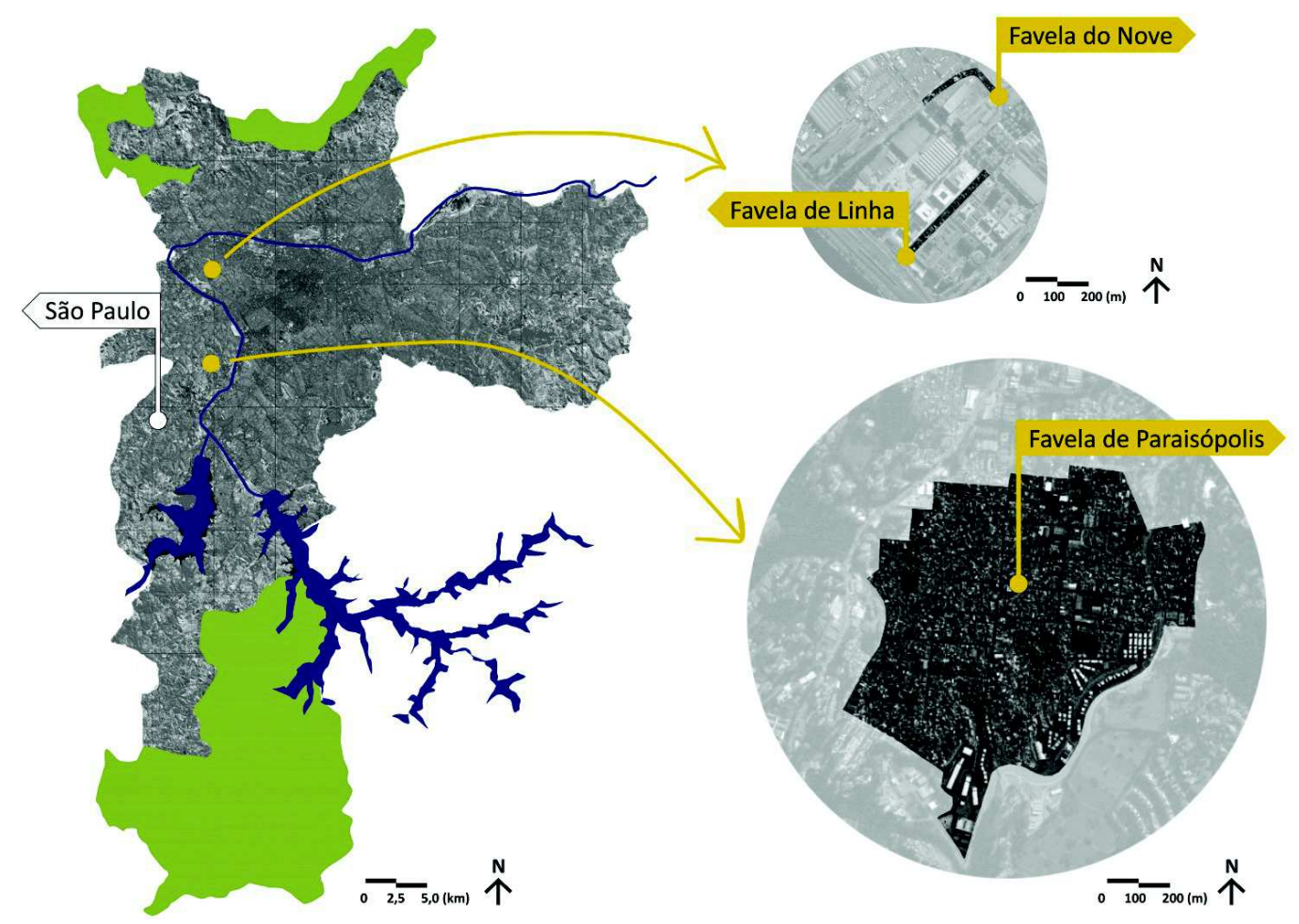

Figura 4 Inserção dos estudos de caso na cidade de São Paulo.

Fonte: Eduardo Pimentel Pizarro, 2015.

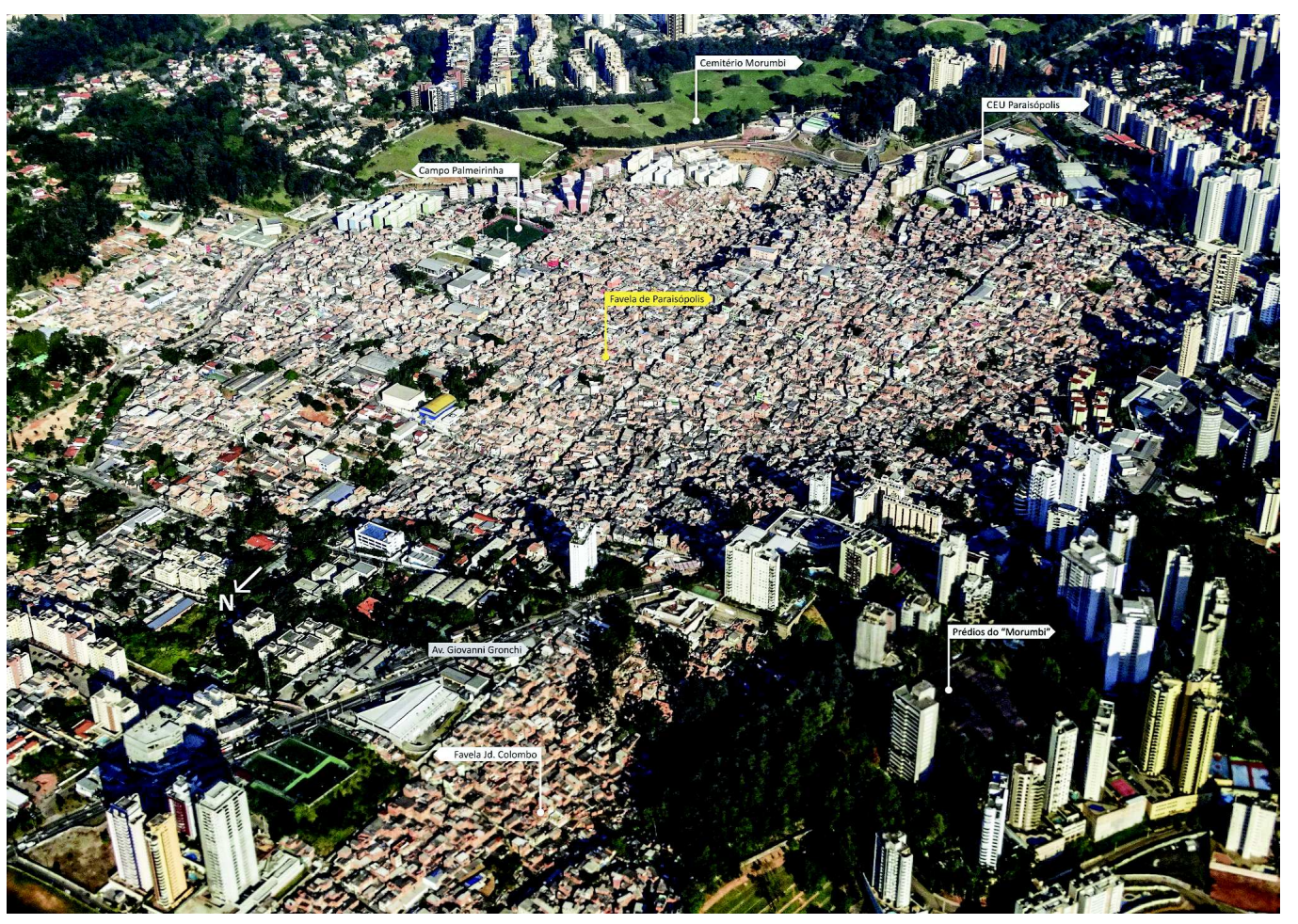

Figura 5 Inserção da favela de Paraisópolis no Morumbi.

Fonte: Trabalho gráfico de Eduardo Pimentel Pizarro sobre foto de Silvio Soares Macedo, 2015. 
(de acordo com estimativas da União dos Moradores e do Comércio de Paraisópolis [UMCP]) - sendo a segunda maior favela do município e a oitava maior do país. As favelas da Linha e do Nove estão localizadas no entorno próximo da Companhia de Entrepostos e Armazéns Gerais de São Paulo (Ceagesp), no distrito da Vila Leopoldina, zona oeste de São Paulo (figura 6).

A favela da Linha ocupa um terreno de propriedade particular com cerca de 8 mil m² (SEHAB, 2011). A ocupação foi iniciada em 1973 (SEHAB, 2011) e, de acordo com moradores, restringia-se, inicialmente, à parcela do terreno de propriedade da empresa Votorantim. Após 1991 passou a ocupar, também, o espaço da via férrea -e hoje é composta por 360 famílias. (INSTITUTO ACAIA, 2013).

A favela do Nove ocupa uma área de propriedade pública com menos de 1 hectare - 7.693,58 $\mathrm{m}^{2}$ (SEHAB, 2011), destinada originalmente a uma via pública, a rua Japiaçu. A ocupação começou em 1972 (HABISP, 2012) e hoje conta com 270 famílias. (INSTITUTO ACAIA, 2013).

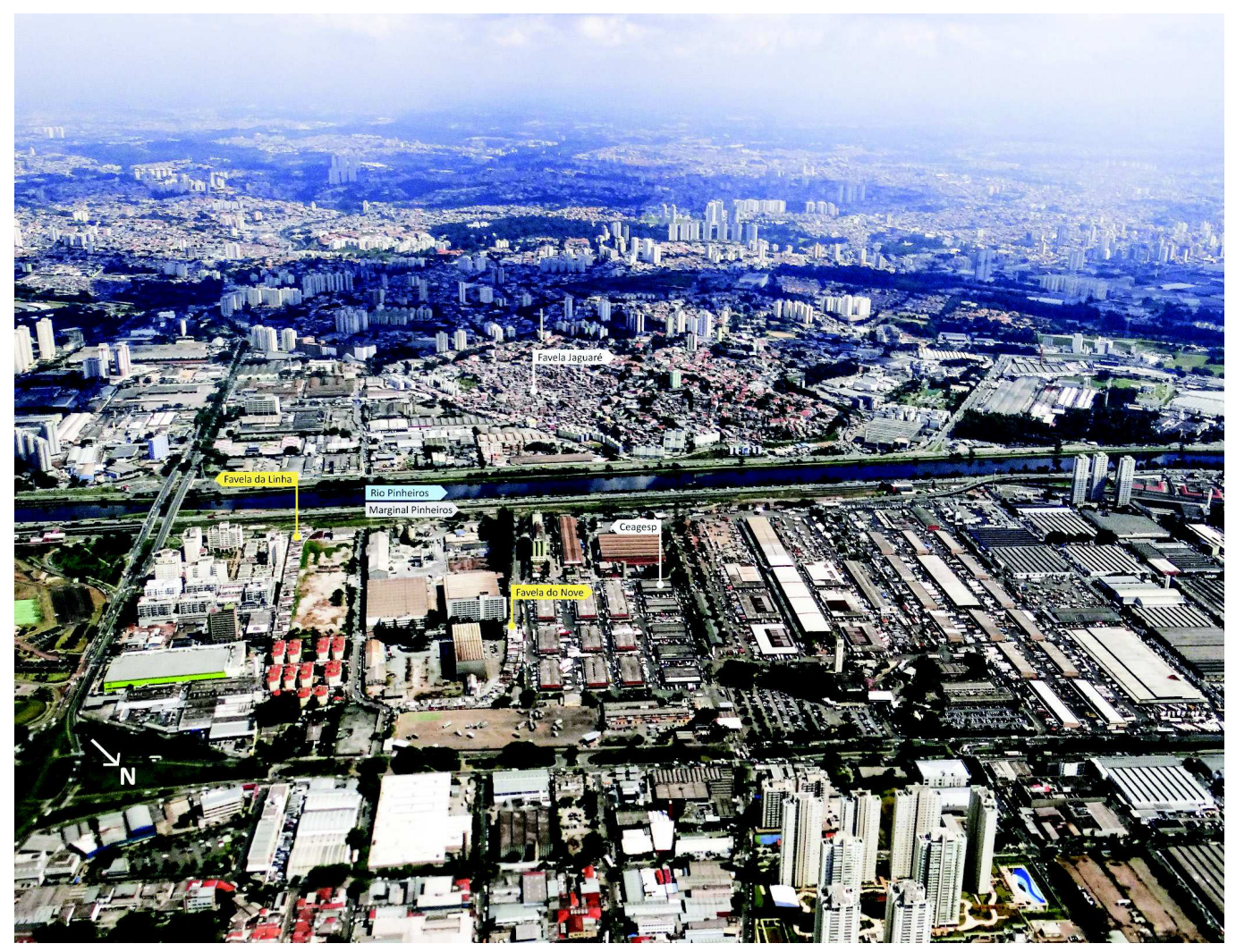

Figura 6 Inserção das favelas da Linha e do Nove na cidade de São Paulo.

Fonte: Trabalho gráfico de Eduardo Pimentel Pizarro sobre foto de Silvio Soares Macedo, 2014.

\section{CARACTERÍSTICAS FÍSICAS}

O SEL de favelas tem como componentes característicos becos, vielas, escadarias e lajes, além de possíveis campos de futebol que, usualmente, constituem espaço livre 
de maior dimensão. Ao longo do tempo, as vielas são delineadas de forma espontânea pelos moradores e constituem parte fundamental dos fluxos cotidianos e da identidade da favela:

Pequenos labirintos [...] Eles têm formatos variados. São íngremes e planos. Alguns são largos e curtos. Outros são sujos e escuros, limpos ou iluminados. Para alguns moradores, esses labirintos se resumem a apenas um caminho de atalho, quando não uma passagem obrigatória. Em Paraisópolis, na Zona Sul de São Paulo, eles são os becos e vielas, responsáveis por interligar ruas umas nas outras, conectar histórias, unir toda a comunidade. (ALENCAR; BELAZI, 2013, p. 30).

Tais espaços livres são ainda precários, principalmente nas favelas da Linha (figura 7) e do Nove (figura 8), no que diz respeito a infraestruturas de saneamento básico, iluminação pública e estado de conservação. Além disso, as vielas raramente são atendidas por serviços como a coleta pública de lixo e o Correio, como mostra o relato de um morador da favela de Paraisópolis:

Cheguei aos Correios, o atendente me disse que custava 10 reais o envio do telegrama. Até aí, tudo bem. Falei o nome da rua, o CEP... Quando eu disse o número da casa, ele alegou que não conferia. Eu disse que morava na Viela da Alegria. Porém, a resposta que recebi foi clara: 'Viela não existe para os Correios'. (ALENCAR; BELAZI, 2013, p. 68).

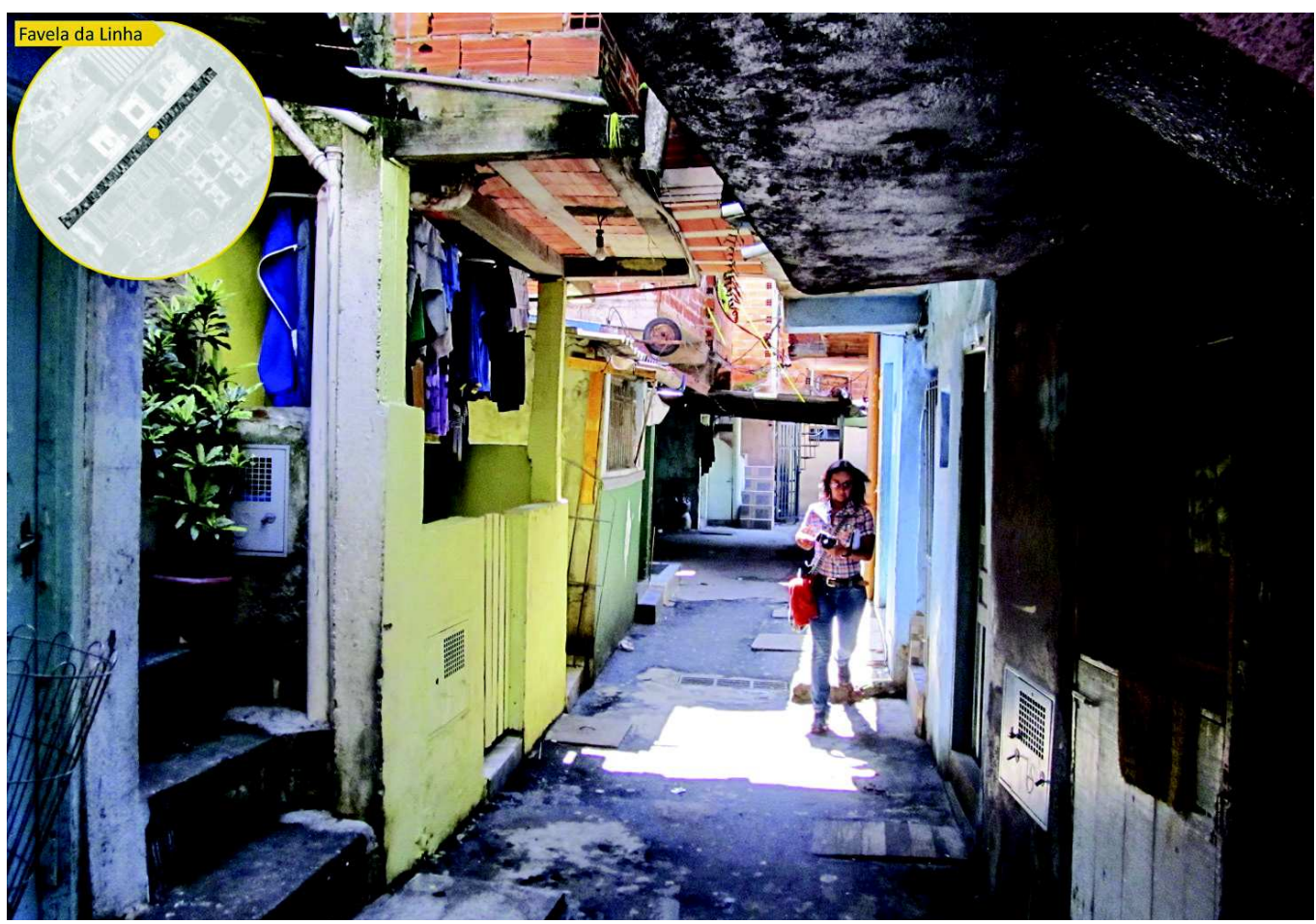

Figura 7 Viela principal da favela da Linha.

Foto: Eduardo Pimentel Pizarro, 2012. 


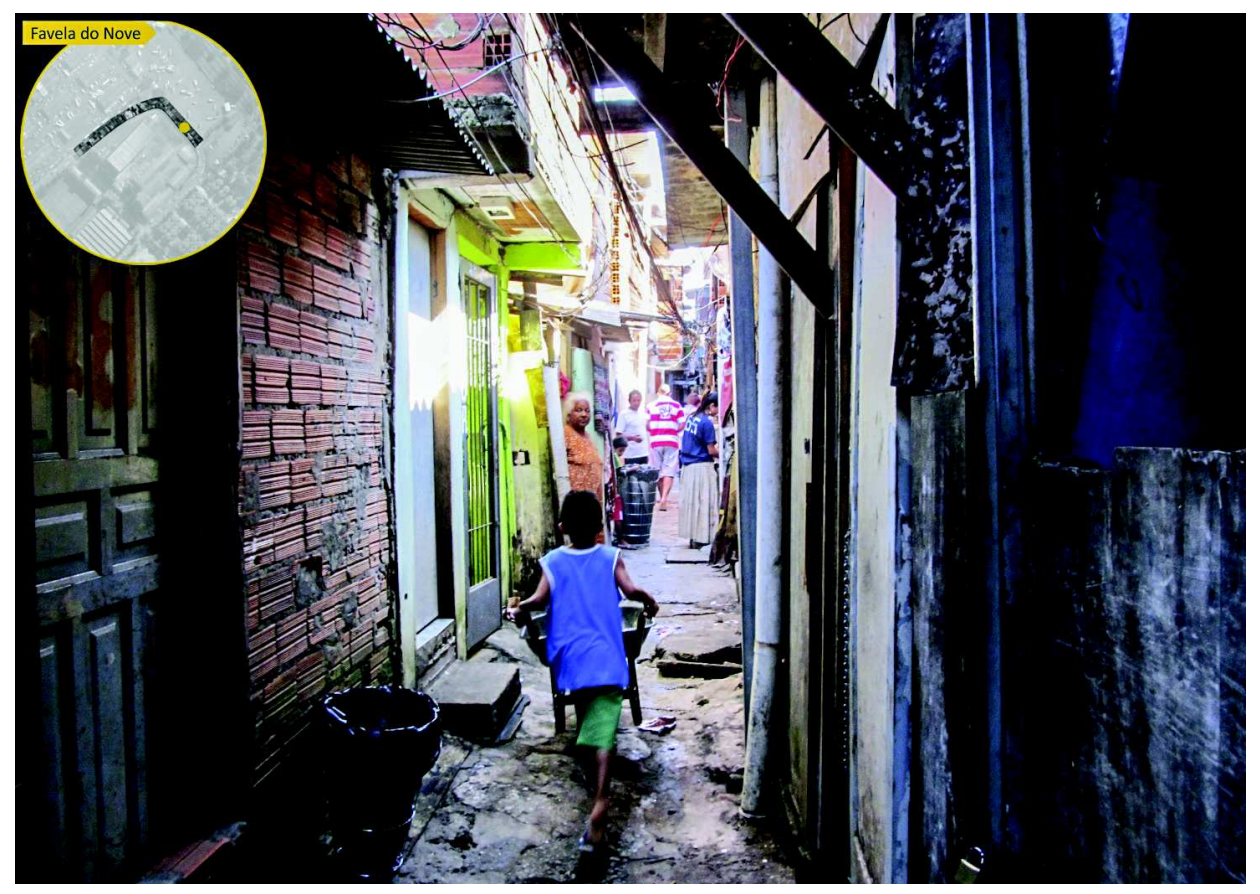

Figura 8 Viela principal da favela do Nove. Foto: Eduardo Pimentel Pizarro, 2012.

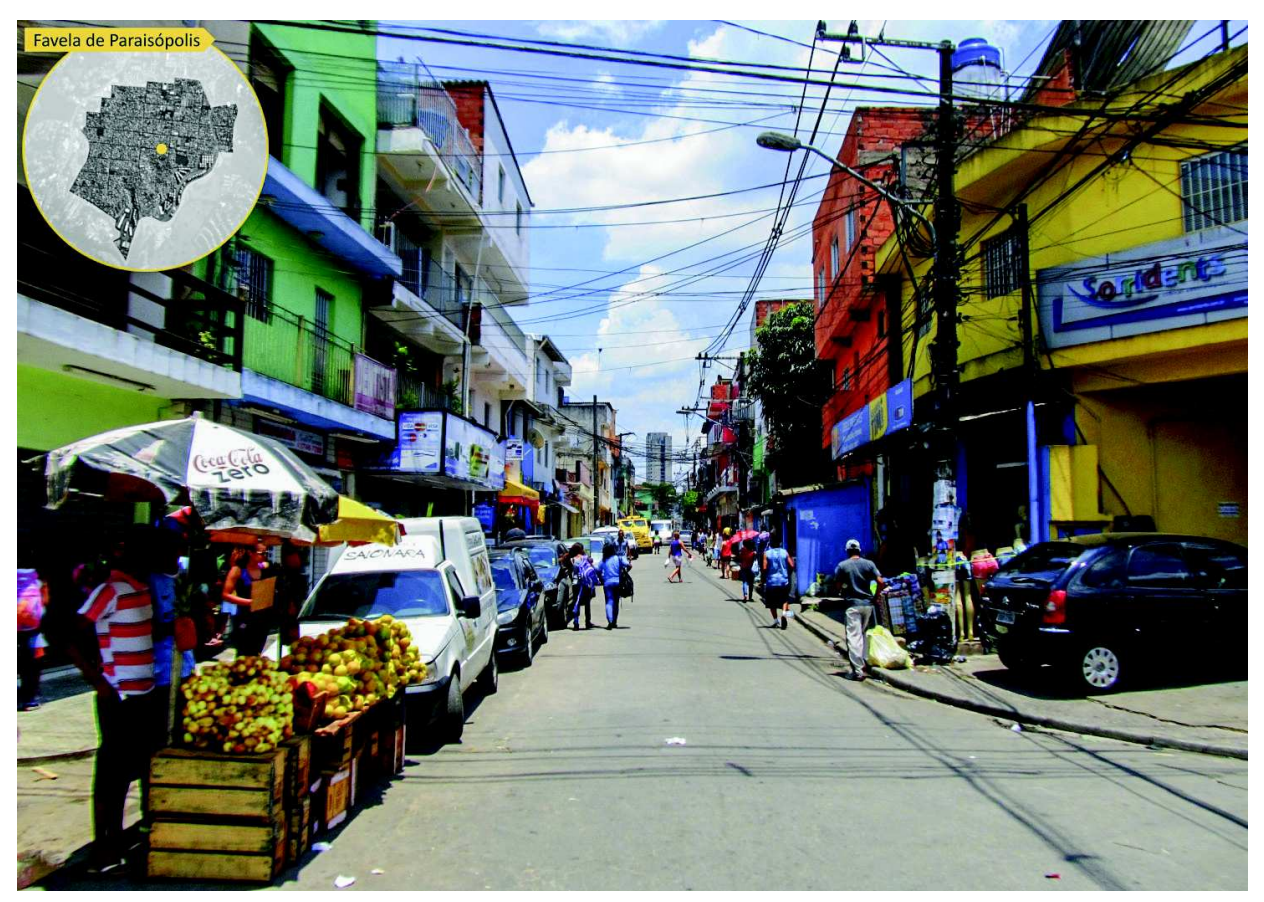

Figura 9 Rua Melchior Giola na favela de Paraisópolis. Foto: Eduardo Pimentel Pizarro, 2014.

Enquanto o SEL das favelas da Linha e do Nove é estruturado, basicamente, por uma única viela principal de pedestres que dá acesso às casas, escadas e lajes, o sistema da favela de Paraisópolis é composto por um extenso sistema ortogonal de ruas 
(figuras 9 e 11), preexistente ao início da ocupação informal, ao qual se sobrepõem redes de lajes, becos e vielas (figuras 10 e 12) no espaço intraquadra. Tal configuração constitui um SEL peculiar, resultado da articulação de formalidades e informalidades, como mostram as figuras 13 a 16 - em planta, perspectiva isométrica explodida, corte e maquete física.

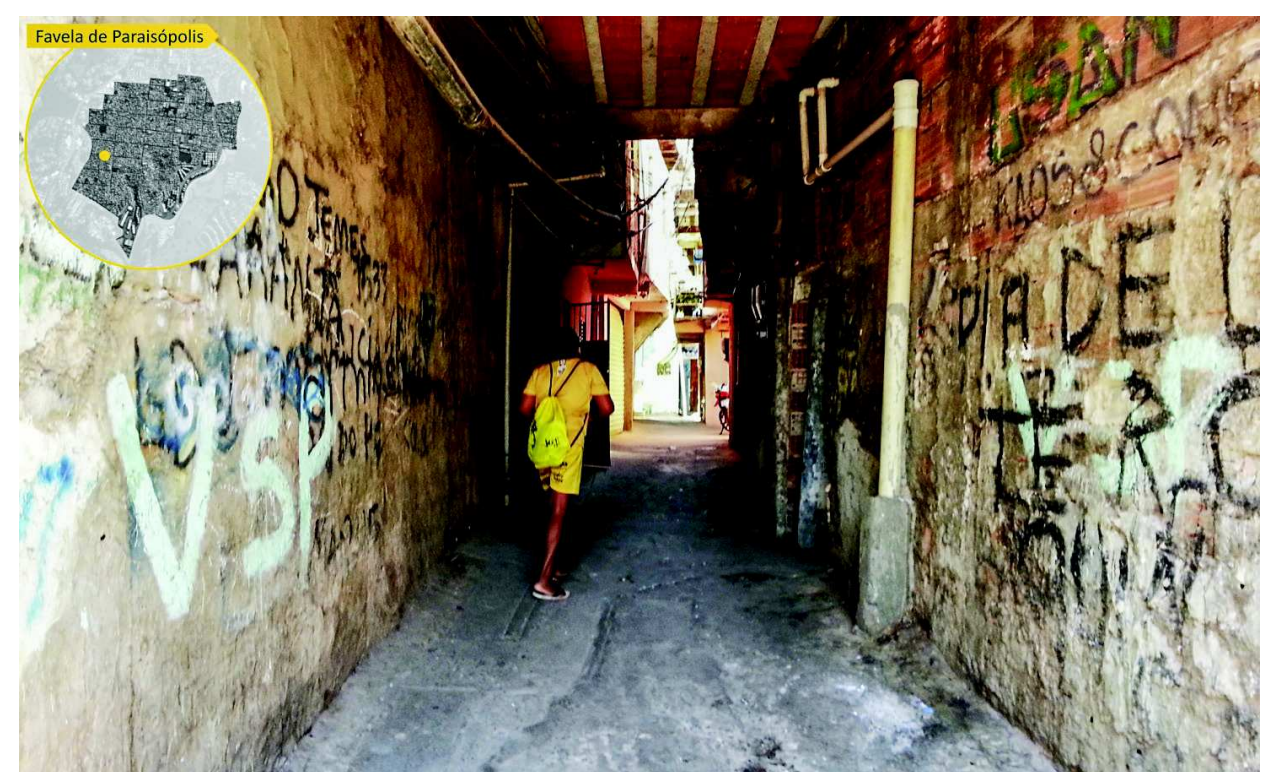

Figura 10 Viela na favela de Paraisópolis.

Foto: Eduardo Pimentel Pizarro, 2014.

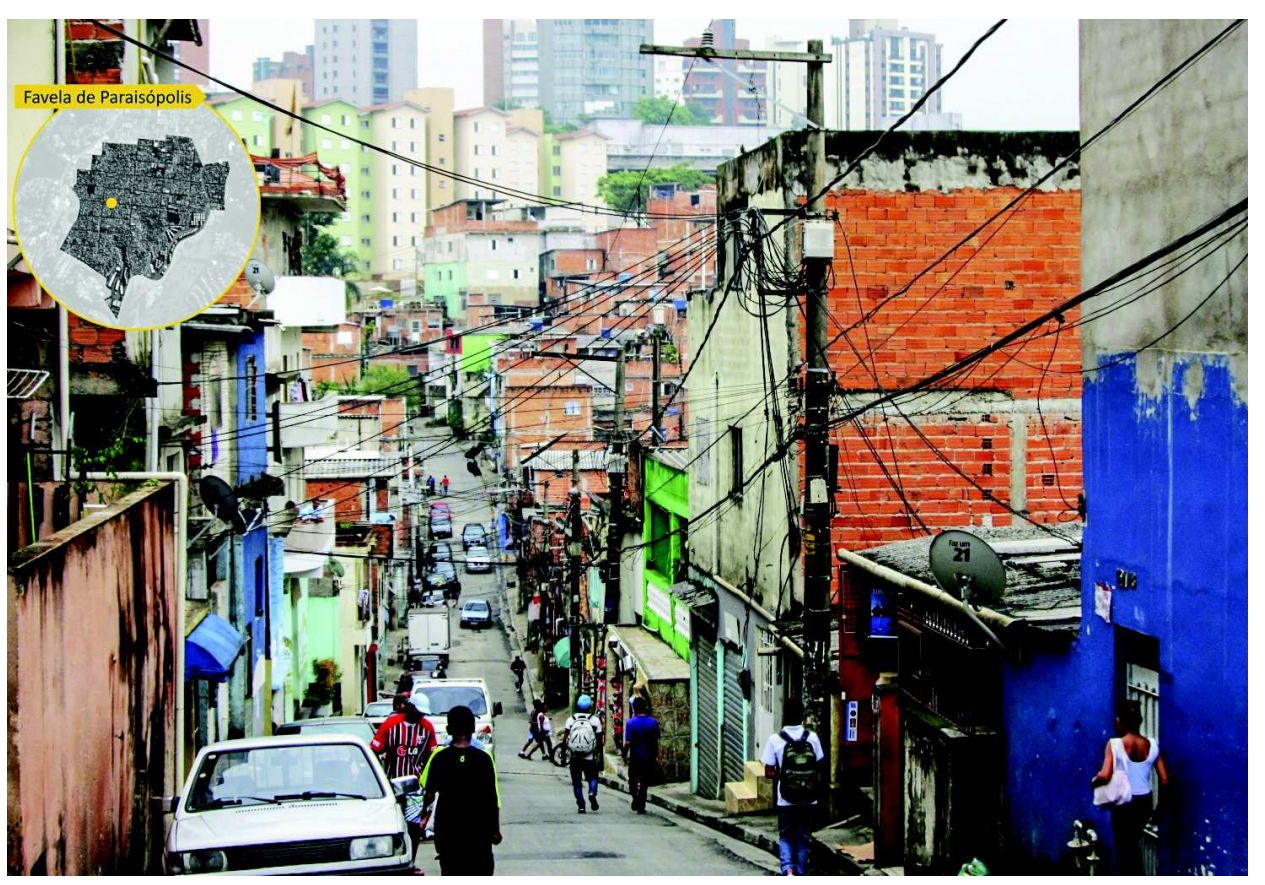

Figura 11 Rua Melchior Giola na favela de Paraisópolis e "Morumbi" ao fundo.

Foto: Eduardo Pimentel Pizarro, 2014. 


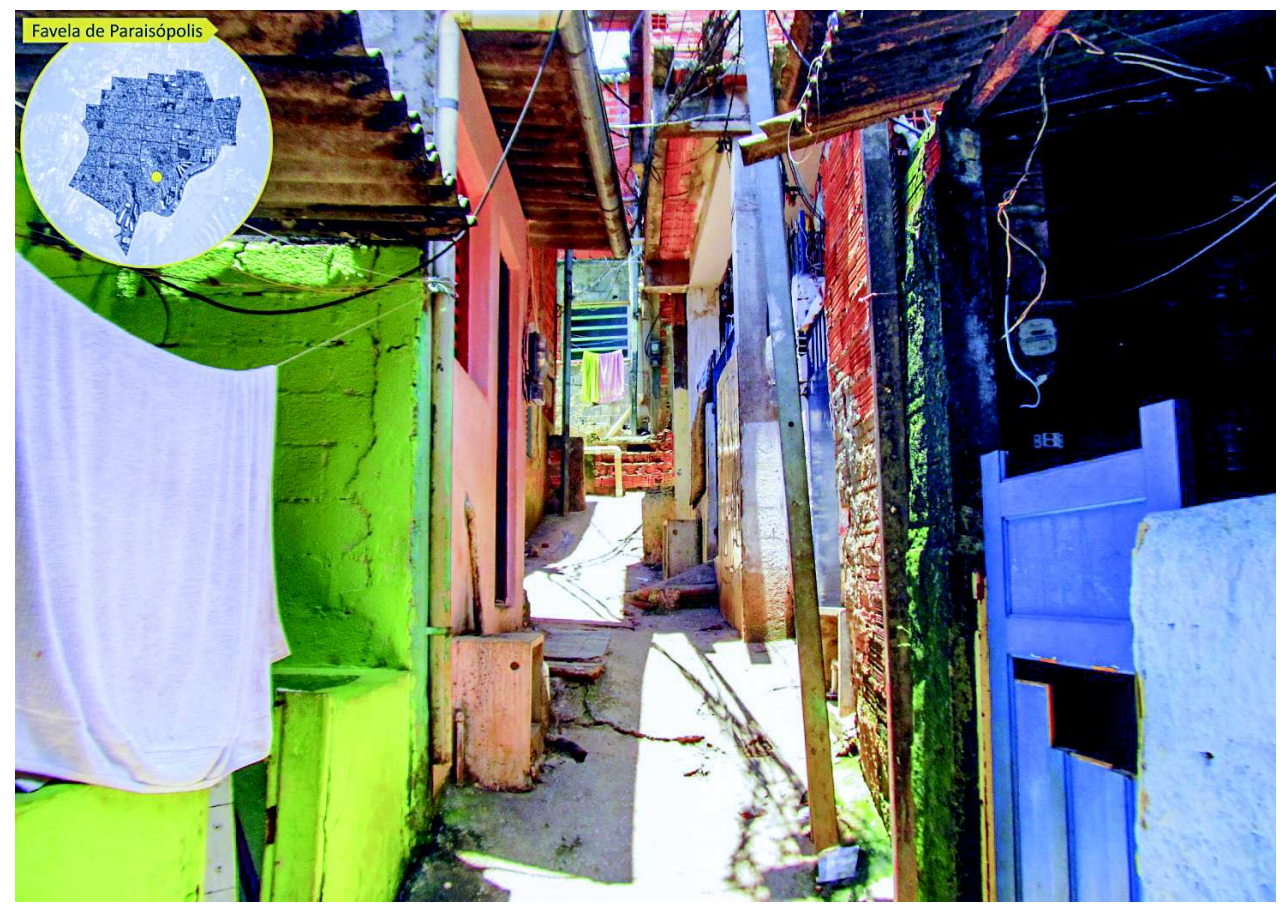

Figura 12 Viela na área do Grotão na favela de Paraisópolis. Foto: Eduardo Pimentel Pizarro, 2014

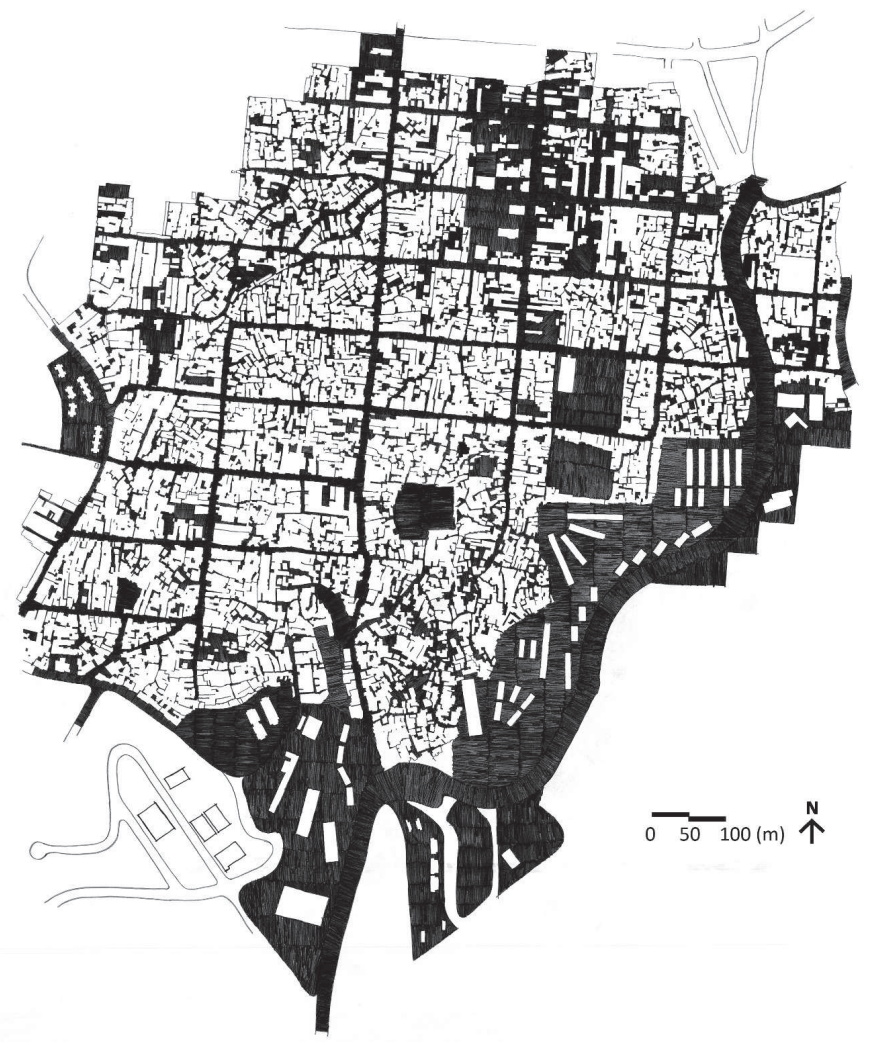

Figura 13 SEL da favela de Paraisópolis em planta. Destaque para a sobreposição entre o sistema viário ortogonal e as redes de vielas no espaço intraquadra.

Fonte: Eduardo Pimentel Pizarro, 2014. 


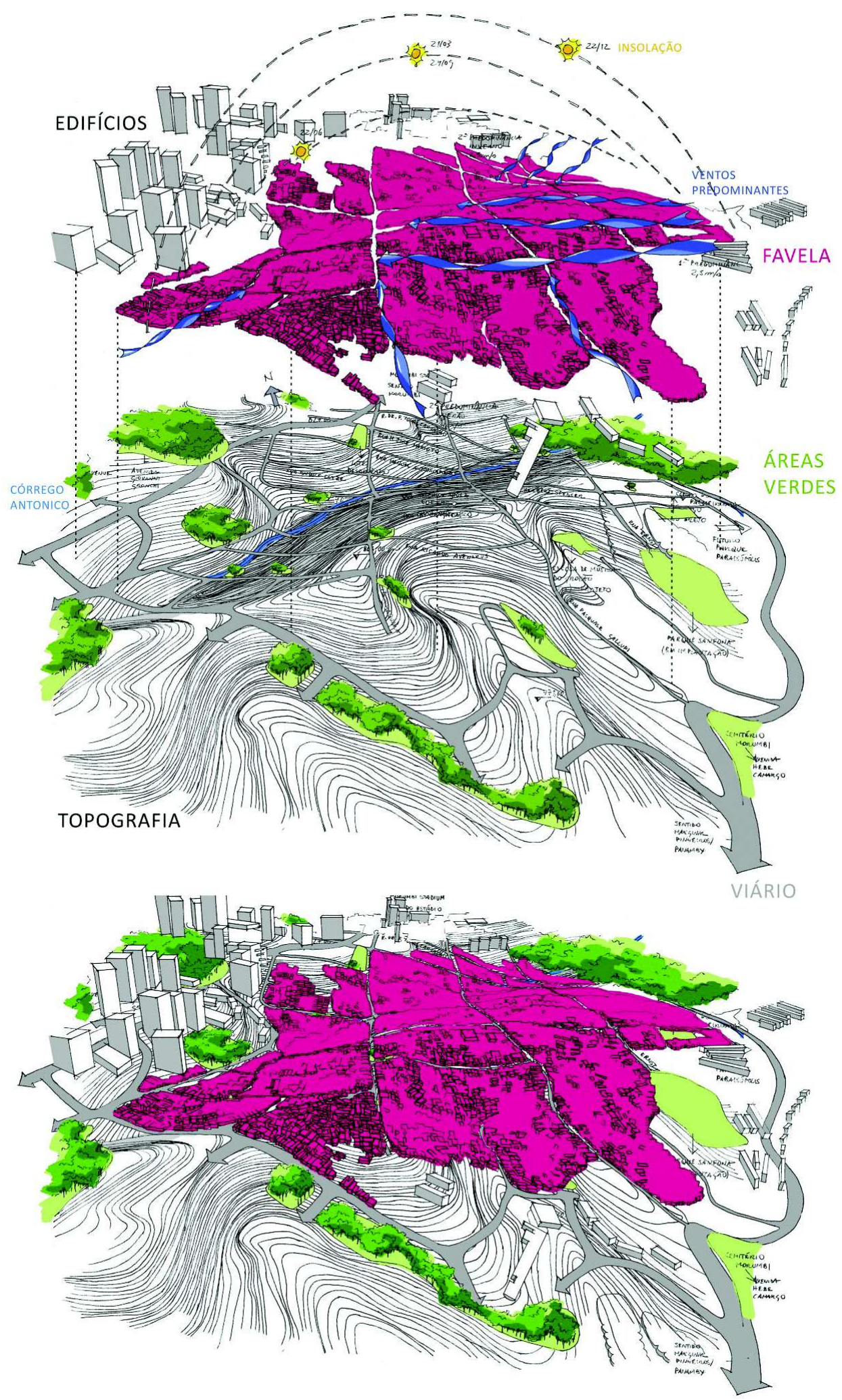

Figura 14 Decomposição das camadas que compõem a favela de Paraisópolis.

Desenho: Eduardo Pimentel Pizarro, 2014. 

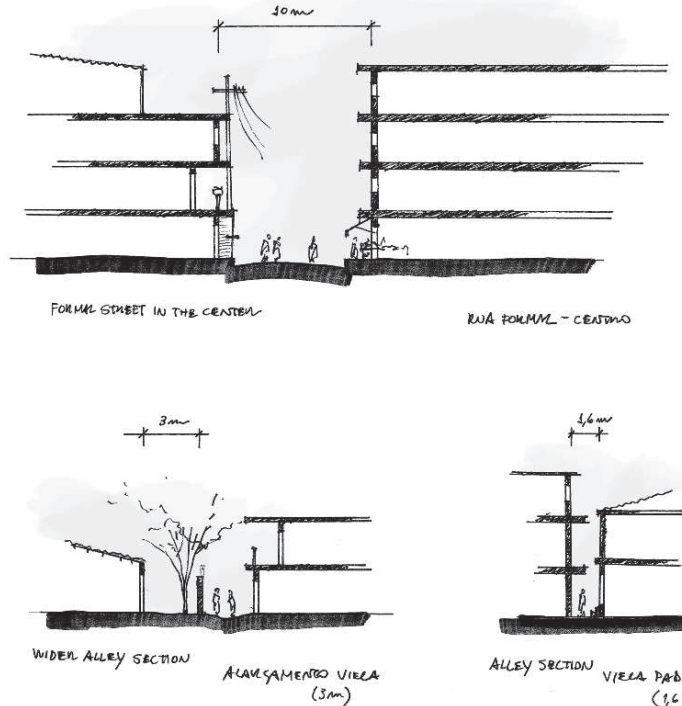

$(3 \mathrm{~m})$
RUA FOMMR - CENONO

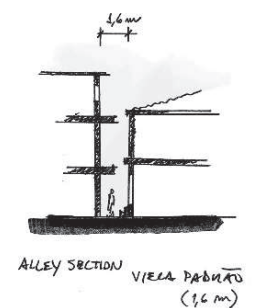

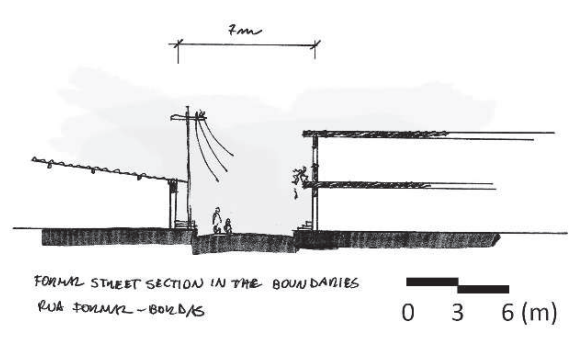

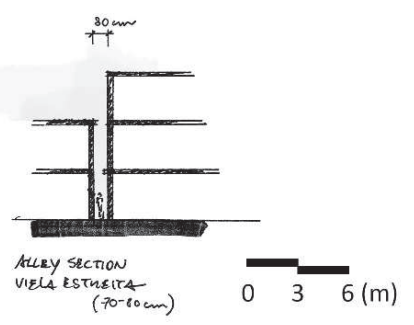

Figura 15 SEL de Paraisópolis em corte. Fonte: Eduardo Pimentel Pizarro, 2014.

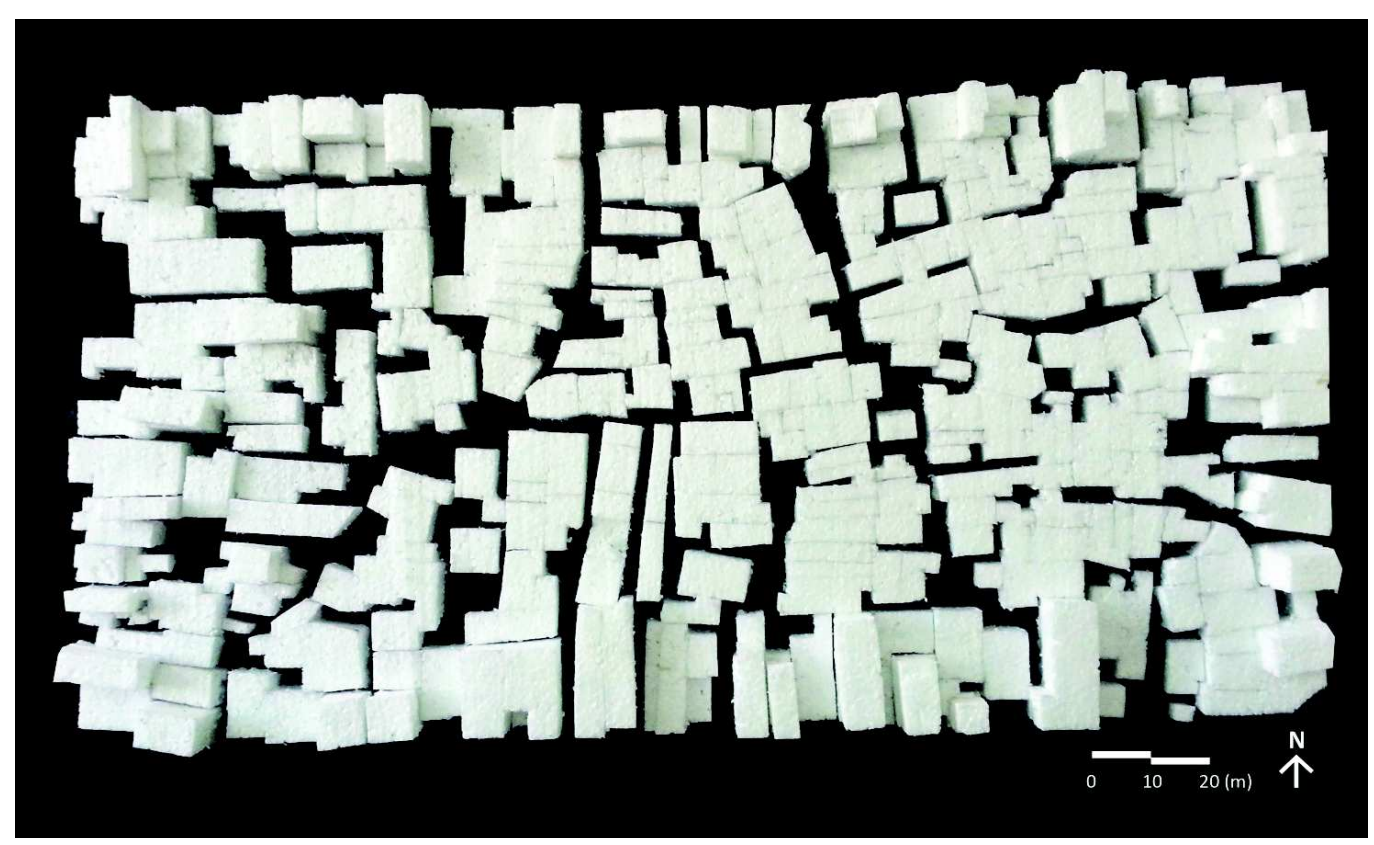

Figura 16 SEL de Paraisópolis na escala da quadra - maquete física. Fonte: Eduardo Pimentel Pizarro, 2014.

Em relação ao sistema viário ortogonal da favela de Paraisópolis, calçadas e ruas são segregadas com guias e sarjetas, como em grande parte da cidade. As calçadas são estreitas e, muitas vezes, fragmentadas por degraus, configurando obstáculos à passagem de pedestres - que andam no leito carroçável em meio a carros, motocicletas, microônibus e bicicletas (figura 17). Na verdade, acabam constituindo um "estoque 
de uso e expansão" para usos comerciais térreos (figuras 17 e 18) e para acesso a pavimentos superiores (figura 19). Seria possível, neste ponto, falar em espacialidades da esfera privada?

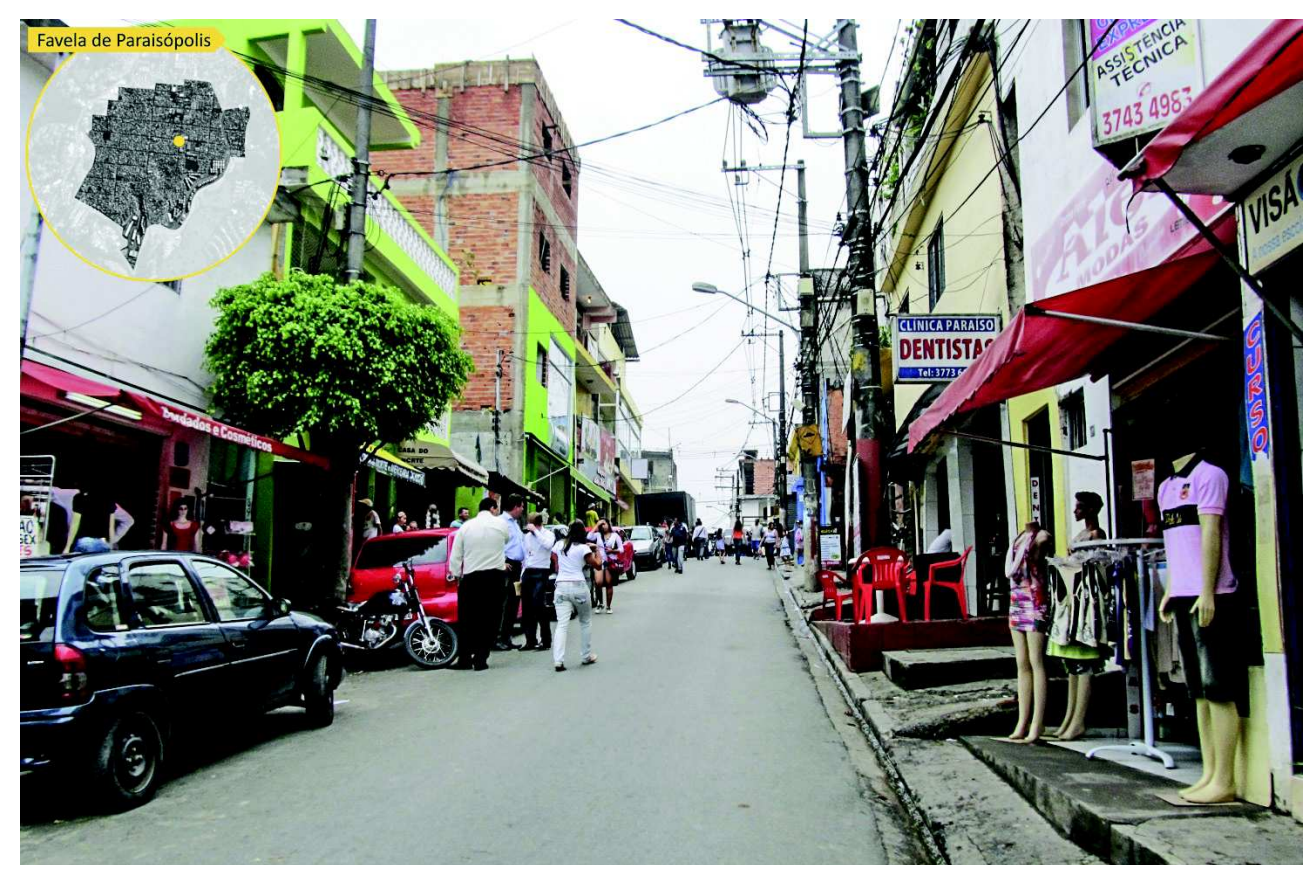

Figura 17 Apropriações de ruas e calçadas na favela de Paraisópolis. Foto: Eduardo Pimentel Pizarro, 2013.

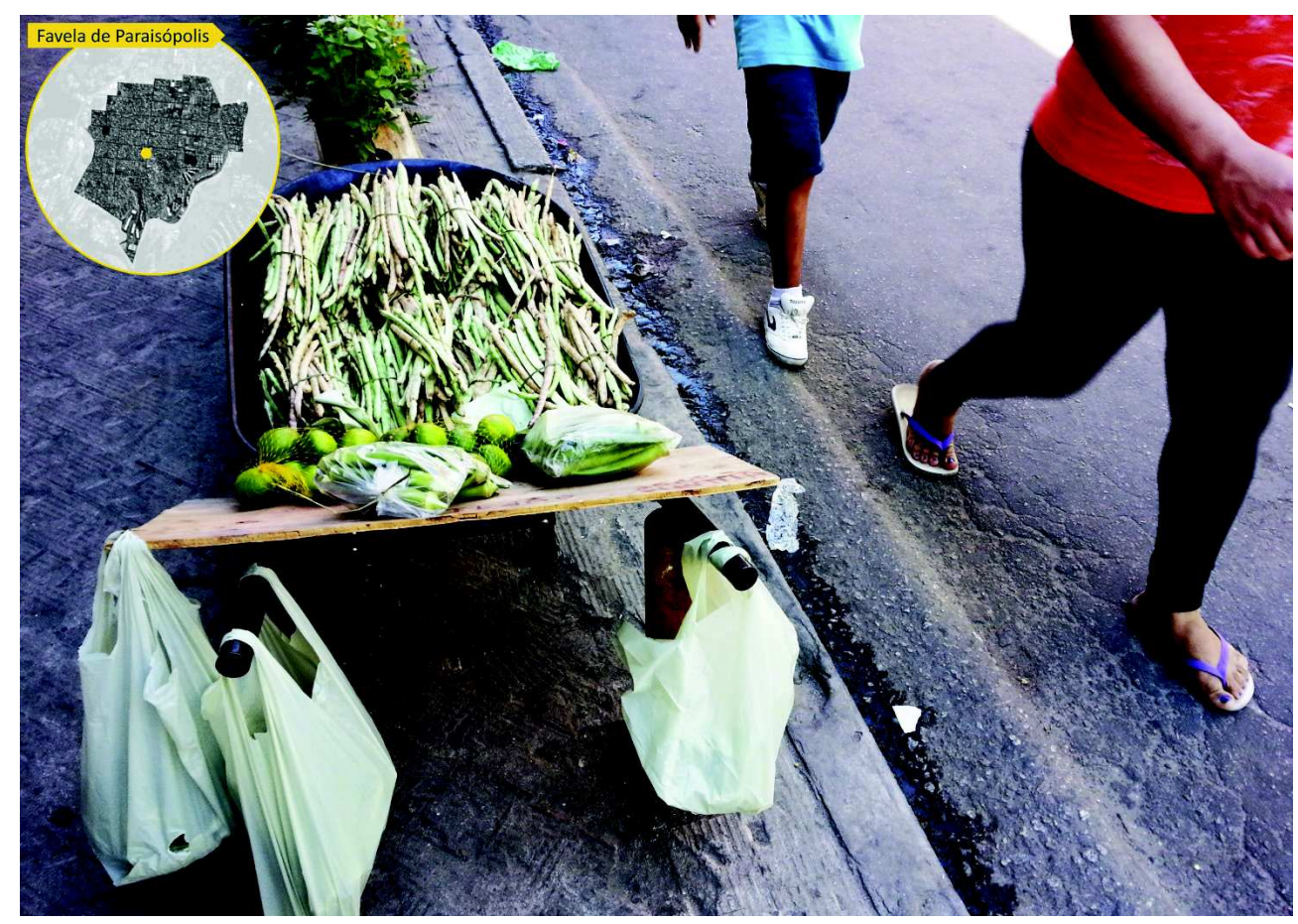

Figura 18 Expansão de usos comerciais na calçada e pedestres nas ruas. Foto: Eduardo Pimentel Pizarro, 2013. 


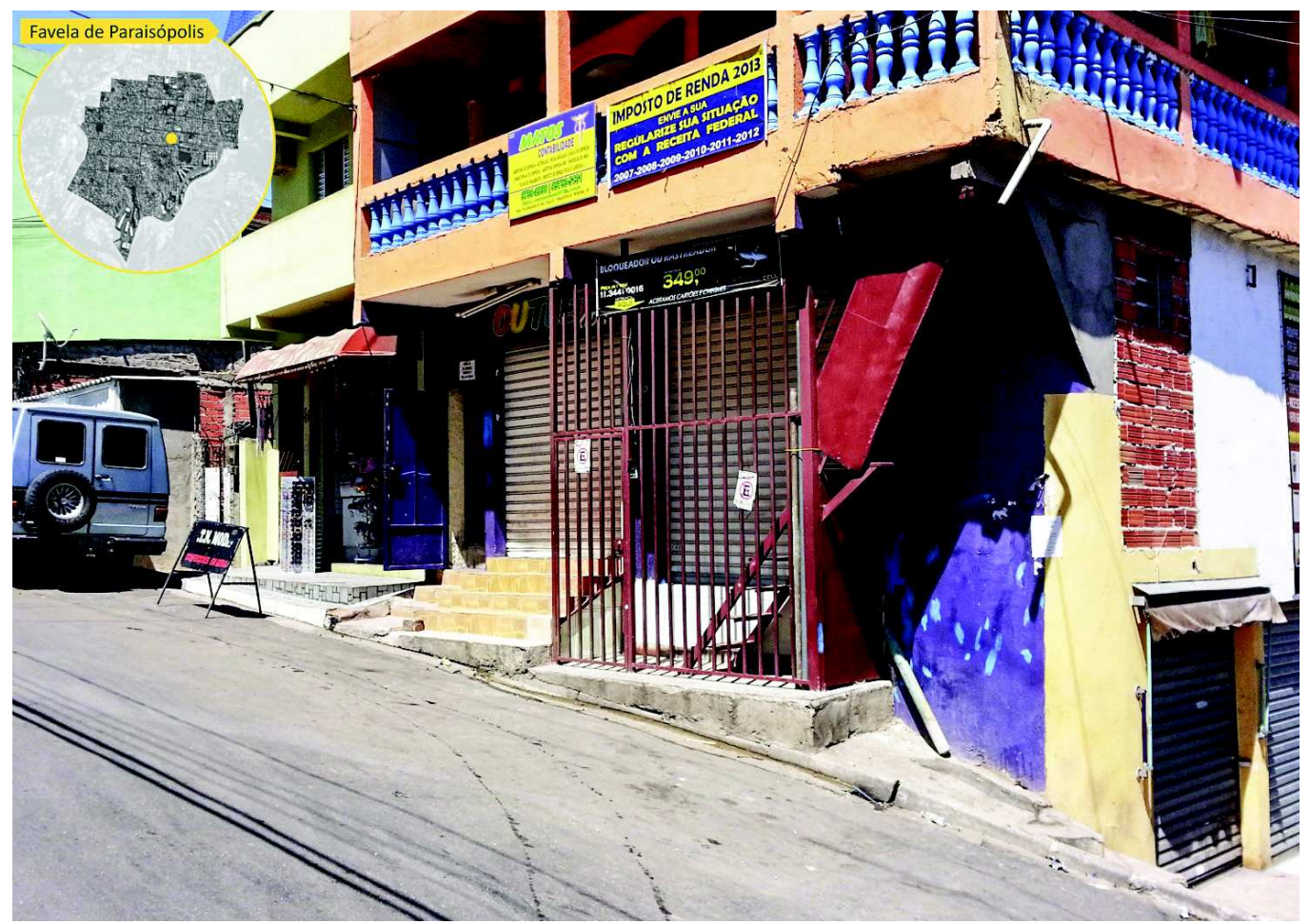

Figura 19 Apropriações das calçadas na favela de Paraisópolis. Foto: Eduardo Pimentel Pizarro, 2013.

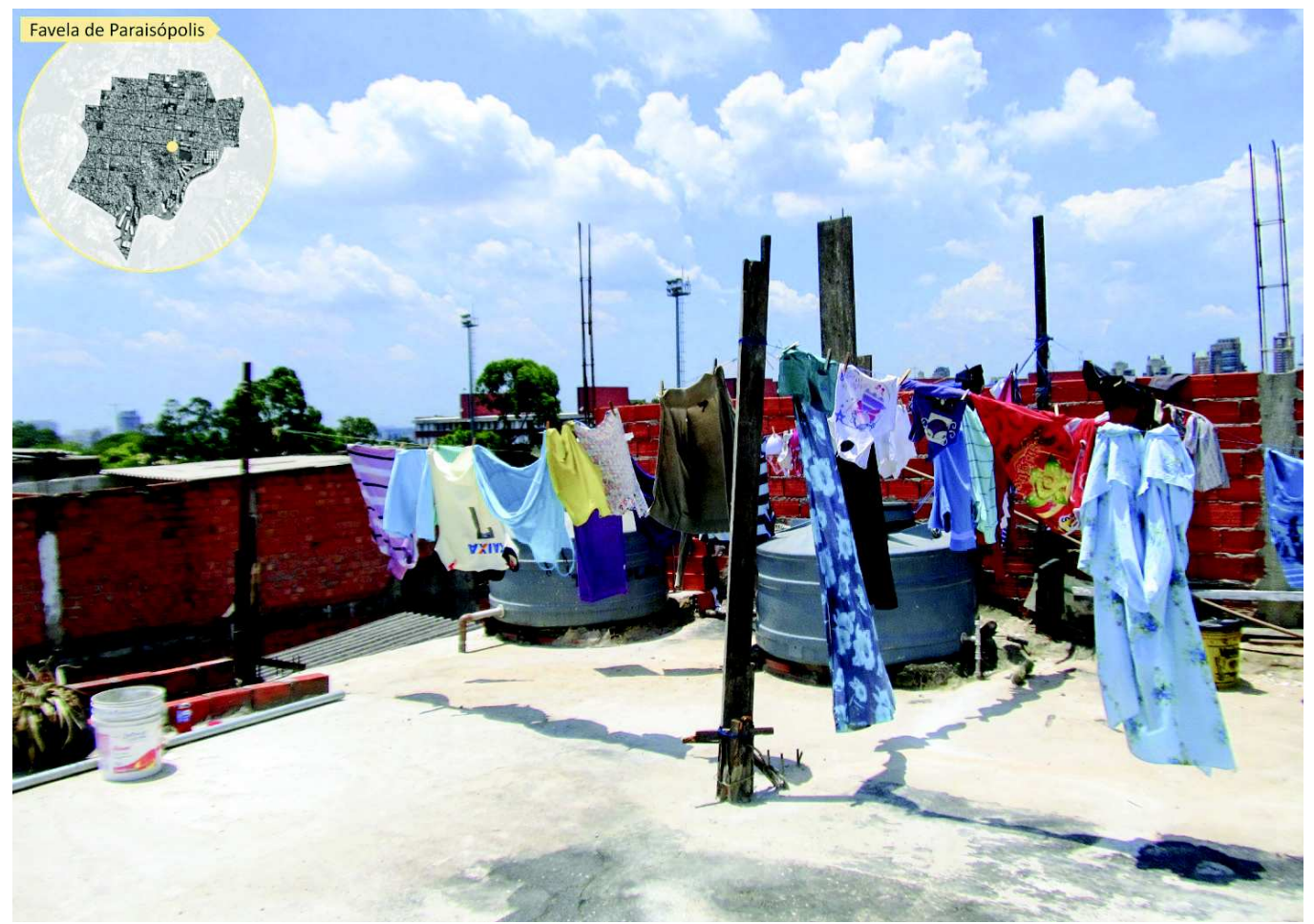

Figura 20 Laje na favela de Paraisópolis (local para estender roupas ou fazer churrascos no final de semana). Foto: Eduardo Pimentel Pizarro, 2013. 


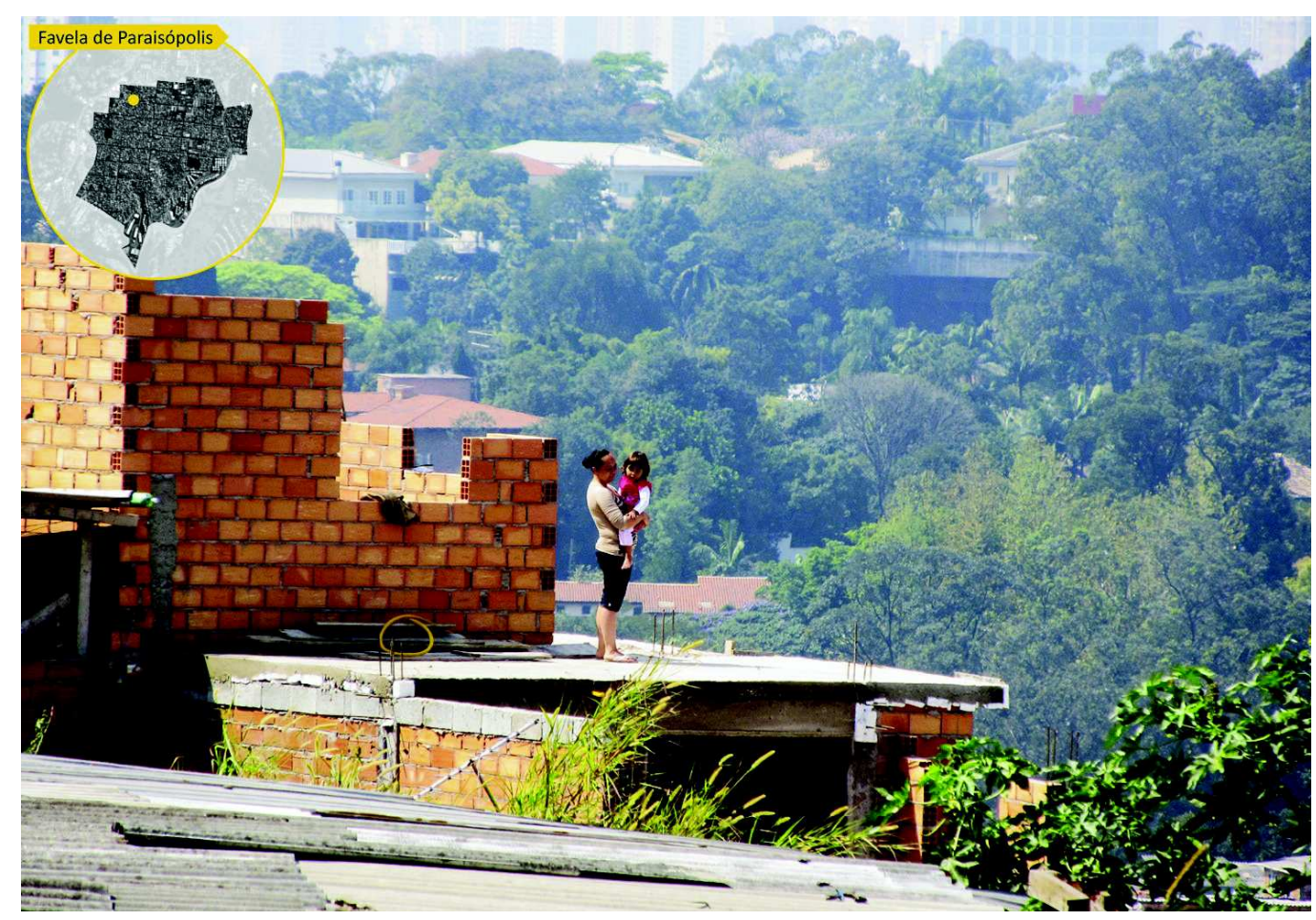

Figura 21 Laje na favela de Paraisópolis e sua importância no processo de crescimento da comunidade. Foto: Eduardo Pimentel Pizarro, 2013.

Assim como os espaços livres situados na cota zero da cidade, as lajes desempenham papel importante na constituição do sistema. Vale destacar que nas favelas a unidade mínima não é a edificação em si, mas a laje que de forma independente pode ser acessada, vendida/alugada, construída/reconstruída, funcionando como um lote urbano da cidade formal (PIZARRO, 2014) que serve tanto a um espaço edificado, quanto a um espaço livre privado, com potenciais práticas de esfera pública (figuras 20 e 21).

\section{PÚBLICO X PRIVADO}

Voltado às favelas de São Paulo, o presente artigo questiona os conceitos de espaço público e privado que tomam por base sua propriedade fundiária legal/regular e propõe a categorização dos mesmos a partir das lógicas de propriedade informais/ irregulares genuínas da própria favela. Isto é, à definição da propriedade fundiária legal das glebas onde estão assentadas as favelas de Paraisópolis (propriedade privada), da Linha (propriedade privada) e do Nove (propriedade pública), é sobreposta a propriedade fundiária informal, que rege as dinâmicas de posse, uso e apropriação estabelecidas pela comunidade ao longo do processo de ocupação: vielas, ruas e campos de futebol são espaços livres públicos; casas são espaços privados; varandas, escadarias e lajes, mesmo sendo espaços livres privados, absorvem diferentes gradientes de práticas públicas (as tais espacialidades da esfera pública), desde secagem coletiva de roupas, até práticas de convívio e lazer, ou simples espaços de passagem, como no 
caso de escadas externas à edificação que garantem acesso a unidades habitacionais independentes em pavimentos diferentes (figura 19).

Partindo dessa reconceituação, vale destacar que na cidade dita informal as interfaces estabelecidas entre espaços livres públicos e privados são mais permeáveis e transicionais. Por exemplo, apesar de existirem portões e grades - elementos que na cidade formal costumam segregar espaços públicos e privados - em varandas, escadas e até em vielas, muitas vezes estão abertos ou destrancados (figuras 22 a 24), ao mesmo tempo em que mantêm a permeabilidade visual e física entre o 'dentro' e o 'fora', o espaço privado e o espaço público (figuras 25). Qual seria, dessa forma, a função de grades e portões nas favelas?

Diferentemente do que afirma Queiroga (2012, p. 117-118) em relação à cidade, "[...] A fragmentação e o isolamento dos espaços livres privados são atributos que, nas cidades brasileiras, caracterizam tais espaços apenas enquanto conjunto de espaços privados, ainda que integrantes de sistemas de espaços livres mais amplos [...]", vale questionar se, no caso da favela, o dito conjunto de espaços livres privados configura um efetivo sistema de espaços livres privados.

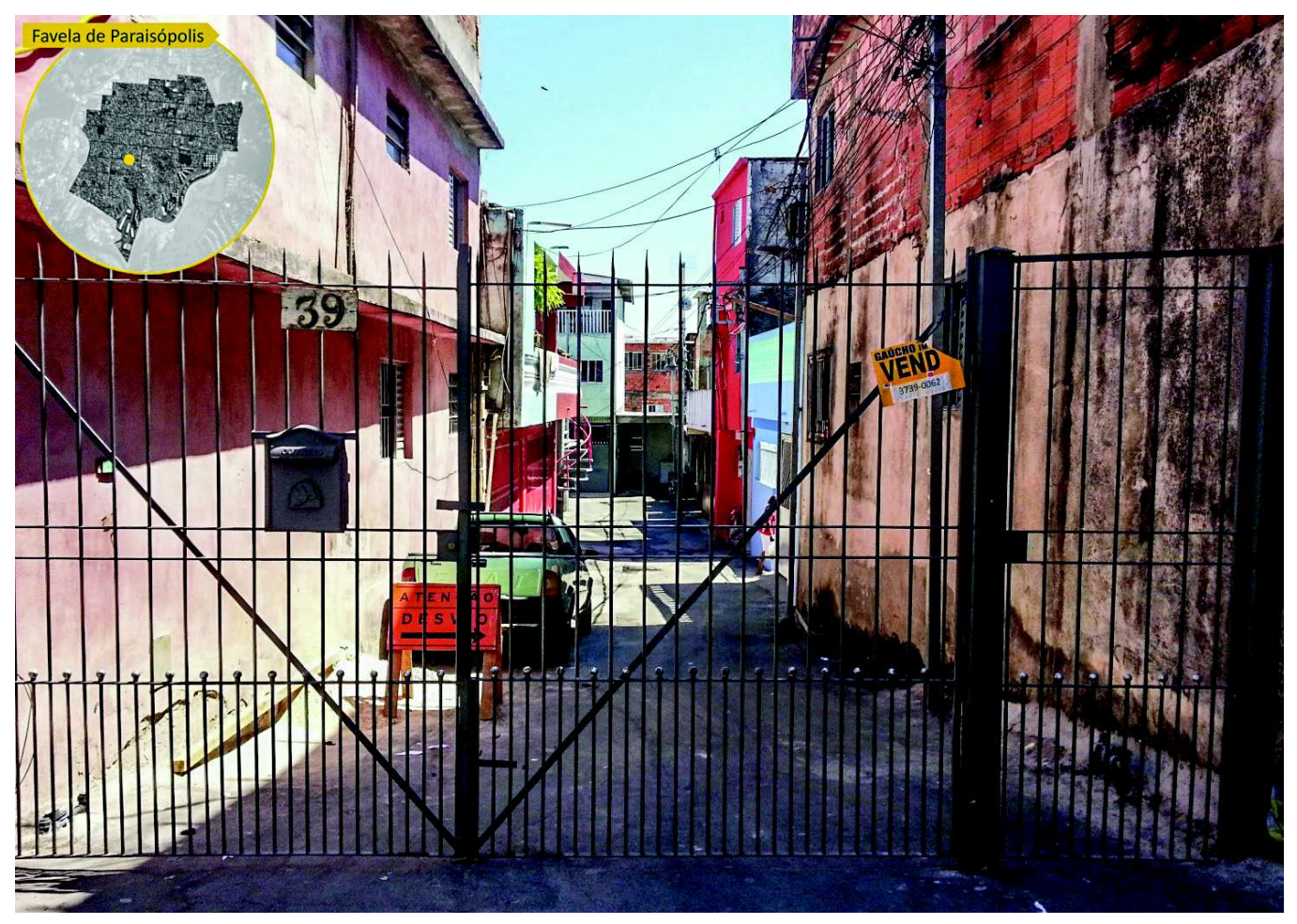

Figura 22 Transições entre espaços públicos e privados na favela de Paraisópolis. Foto: Eduardo Pimentel Pizarro, 2013.

\section{ESPACIALIDADES DA ESFERA PÚBLICA}

Ao seguir adiante pela Viela, a primeira manobra. Vira-se à esquerda. A boa notícia é que há mais espaço de um canto ao outro, onde crianças correm e espalham 
Sistema de Espaços Livres e Espacialidades da Esfera Pública em Favela: Os Casos de Paraisópolis, da Linha e do Nove em São Paulo
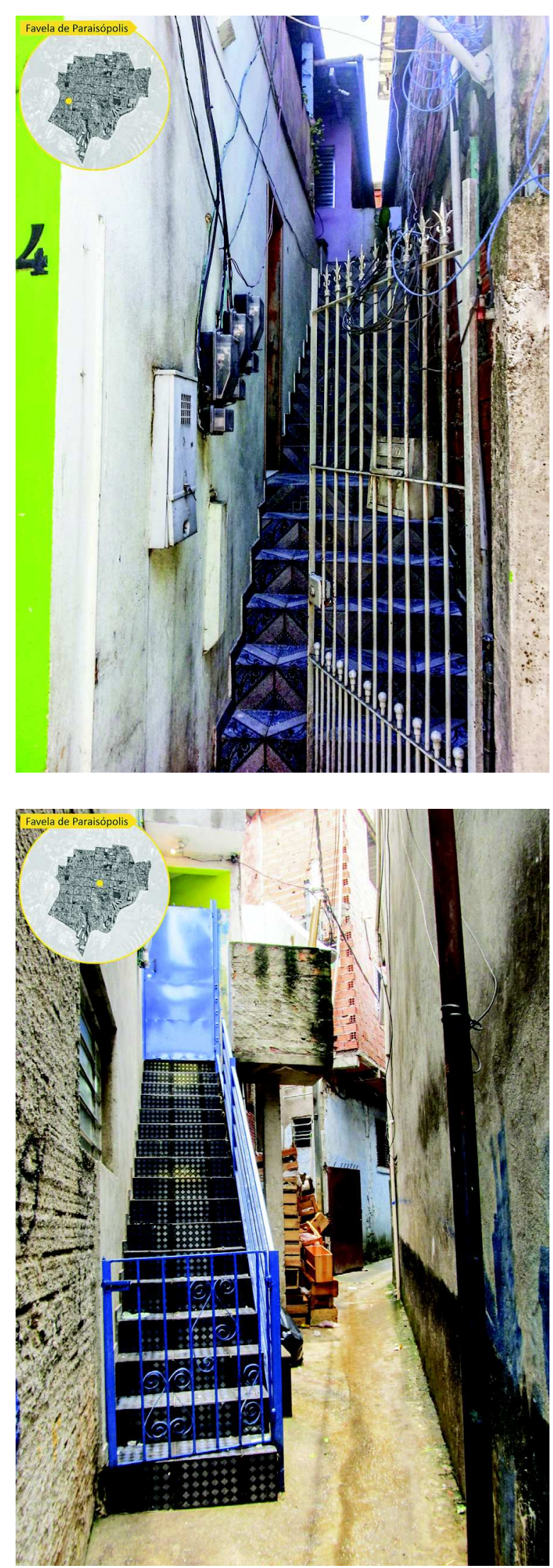

Figura 23 Transições entre espaços públicos e privados na favela de Paraisópolis.

Foto: Eduardo Pimentel Pizarro, 2013.

Figura 24 Transições entre espaços públicos e privados na favela de Paraisópolis. Foto: Eduardo Pimentel Pizarro, 2013. 


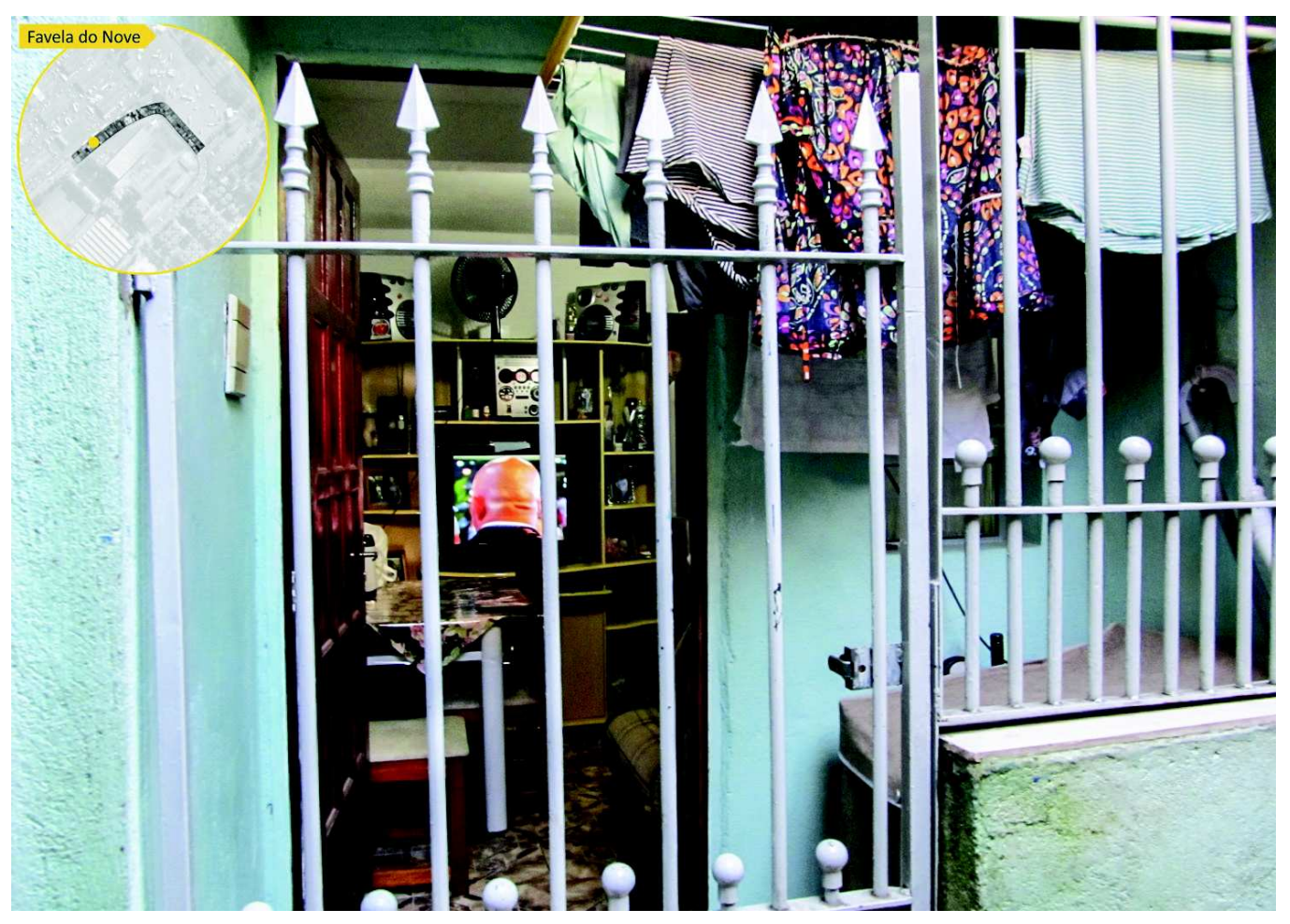

Figura 25 Interface entre espaço público e privado. Grades destrancadas e permeabilidade visual direta na favela do Nove.

Foto: Eduardo Pimentel Pizarro, 2012.

brinquedos pelo chão. Mulheres assentam cadeiras do lado de fora ou se sentam nas muretas que protegem suas casas quando a enchente insiste em adentrar as moradias. Sentadas ou em pé, elas tagarelam e sorriem. Outros sorrisos são ouvidos de cima. Inúmeras escadas vão mostrando que existem outros lares no alto. (ALENCAR; BELAZI, 2013, p. 40).

A citação anterior relata as espacialidades da esfera pública desenvolvidas em um espaço livre público, a viela Amadeu na favela de Paraisópolis. As "[...] relações de vizinhança são marcadas por intensa sociabilidade, com forte valorização dos espaços comuns como lugar de encontro". (OBSERVATÓRIO DE FAVELAS apud GROSBAUM, 2012 , p. 31). Esse tipo de sociabilidade é observado também nas vielas das favelas da Linha (figura 26) e do Nove (figura 27), onde se destaca a importância das atividades comerciais e do espaço em frente às portas como estimuladores das espacialidades da esfera pública.

As espacialidades da esfera pública podem transformar-se em períodos específicos da semana ou do dia, como nos casos da feira livre semanal da rua Ernest Renan e do campo de futebol do Palmeirinha na favela de Paraisópolis, que servem a diferentes eventos comunitários ou à roda de samba no final da tarde - mesmo depois da intervenção que trouxe grama sintética, cercado de tela metálica e controle de acesso (figura 28) para o antigo campo de terra batida. 


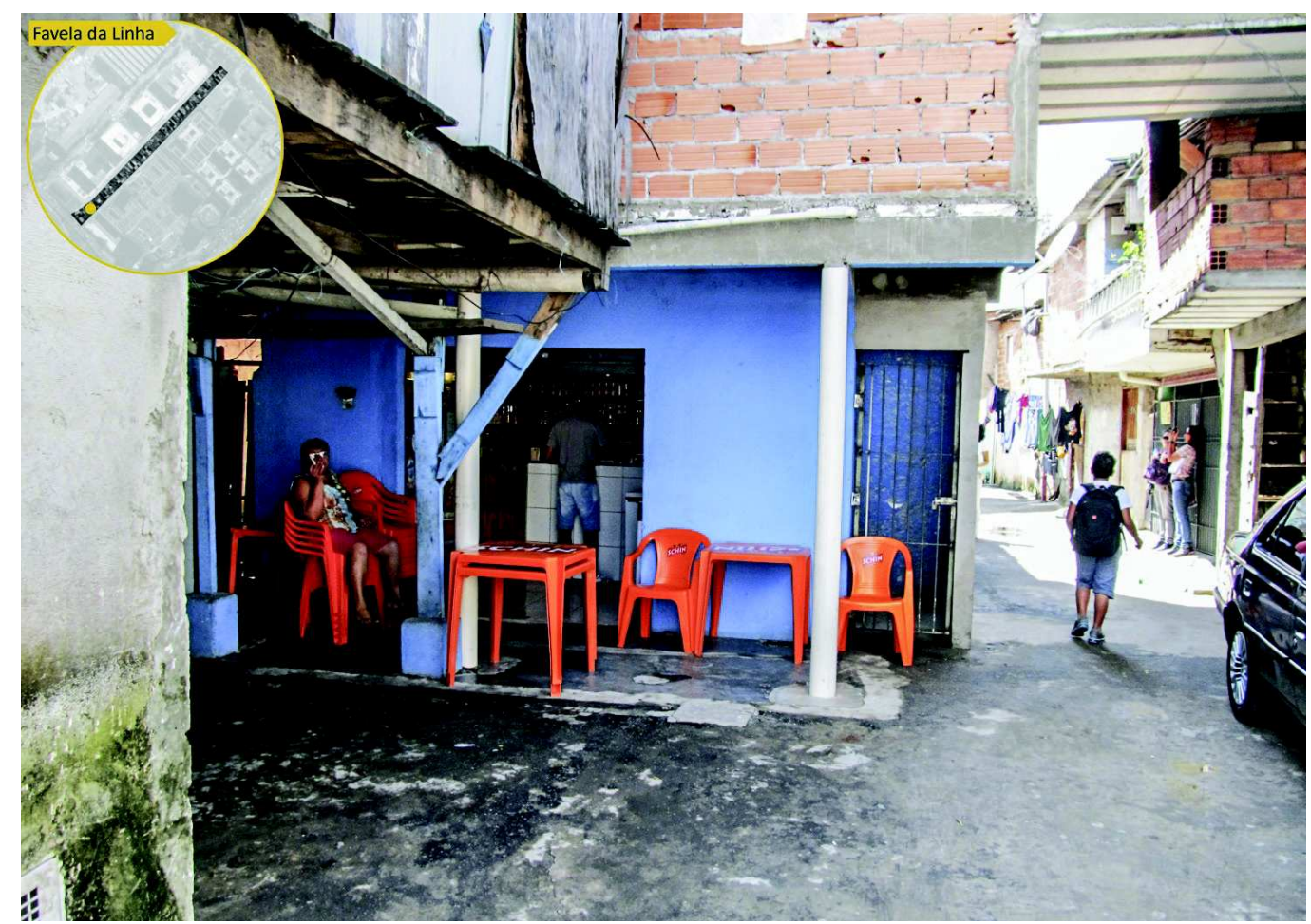

Figura 26 Favela da Linha.

Foto: Eduardo Pimentel Pizarro, 2012

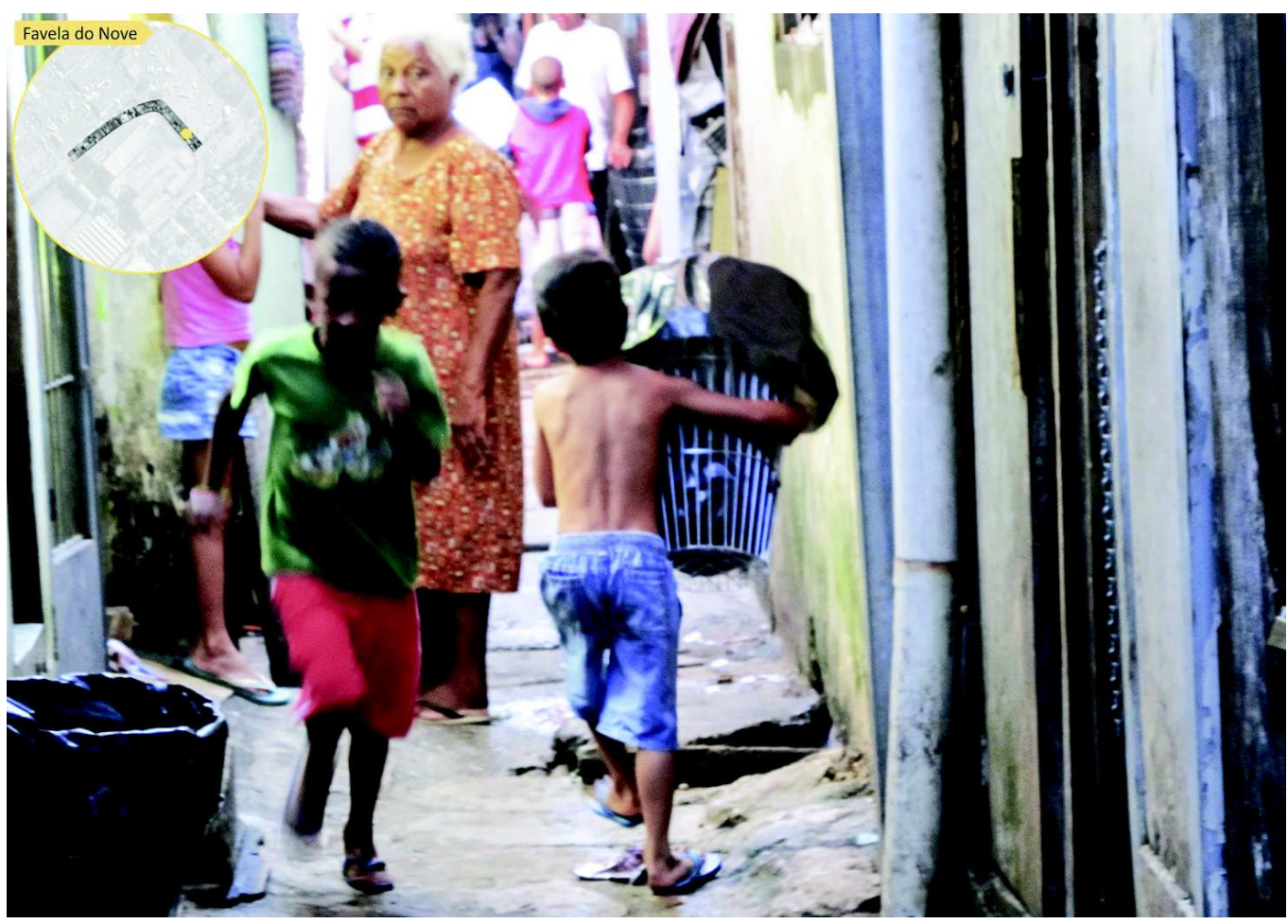

Figura 27 Favela do Nove.

Foto: Eduardo Pimentel Pizarro, 2012. 


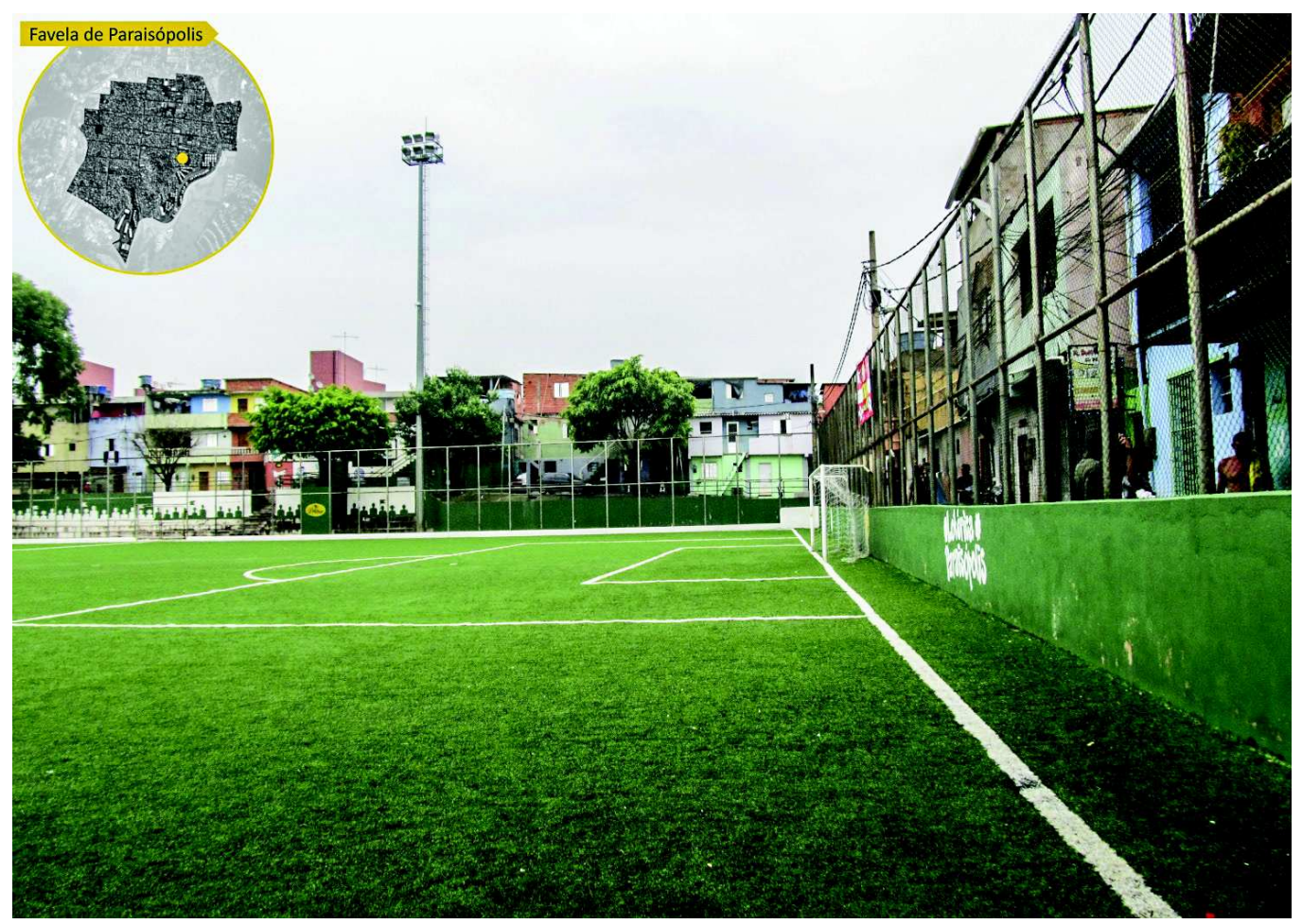

Figura 28 Campo do Palmeirinha na favela de Paraisópolis. Foto: Eduardo Pimentel Pizarro, 2014

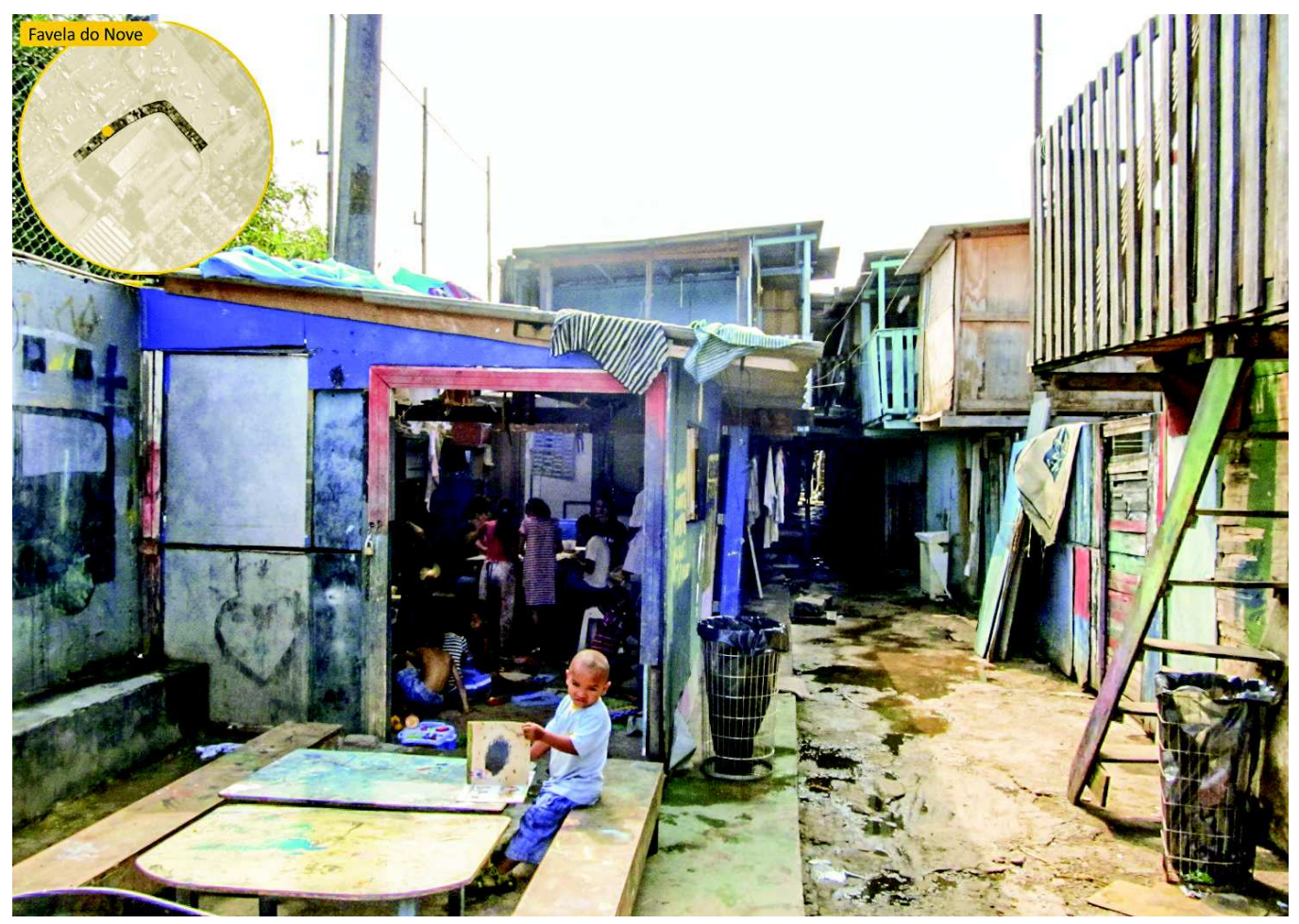

Figura 29 Favela do Nove.

Foto: Eduardo Pimentel Pizarro, 2012. 
Da mesma forma, a espacialidade da esfera pública pode ser 'construída' por meio de pequenas intervenções, como a substituição, feita pelo Instituto Acaia, de um depósito de lixo na favela do Nove por uma praça junto a um centro comunitário (figura 29), voltada ao desenvolvimento de atividades de arte (ROSA, 2011), espaço de conversa e encontro, ou espaço para pendurar roupas para secar.

Além dos espaços livres públicos, como vielas e ruas, as espacialidades da esfera pública são significativas em espaços fechados - a exemplo do espaço da lavanderia Ponto de Encontro, criada pelo Instituto Acaia na favela da Linha (figura 30) - e em espaços livres privados. Estes podem ser varandas, que, lado a lado ou frente a frente, configuram espaços livres privados com contato público; escadas abertas que vêm desde a calçada, configurando 'arquibancadas à vida pública', passando pela frente das janelas dos vizinhos até as coberturas; lajes, que configuram espaço para secagem compartilhada de roupas ou festas e churrascos em finais de semana. Enfim, para Grosbaum (2012) as espacialidades da esfera pública em assentamentos informais se dão onde é possível, muitas vezes de forma 'promíscua', com a vida privada. A figura $31 \mathrm{faz}$ um contraponto a essa situação na medida em que defende uma separação clara entre as esferas pública e privada.

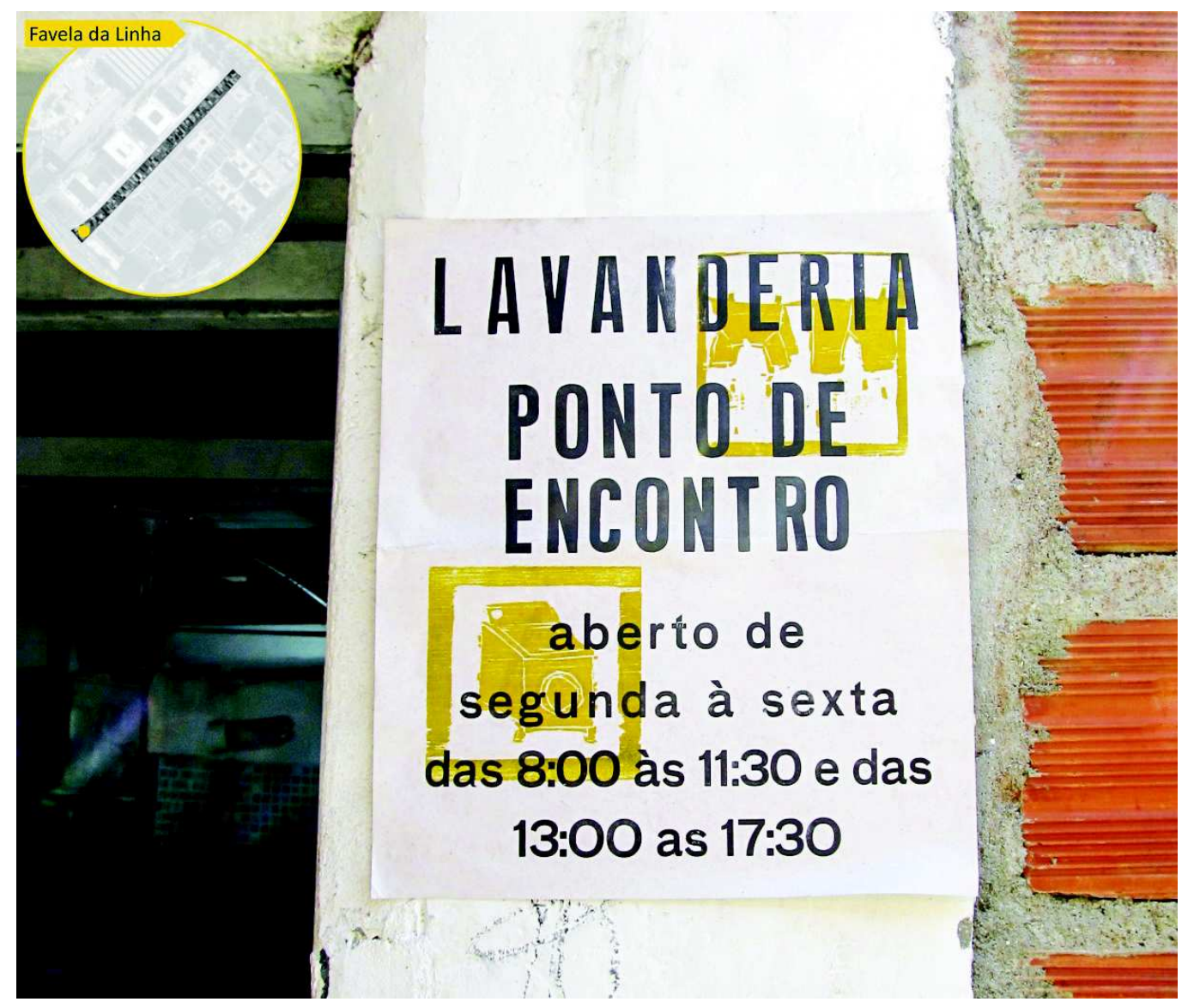

Figura 30 Lavanderia Ponto de Encontro, espaço privado com práticas públicas. Foto: Eduardo Pimentel Pizarro, 2012. 


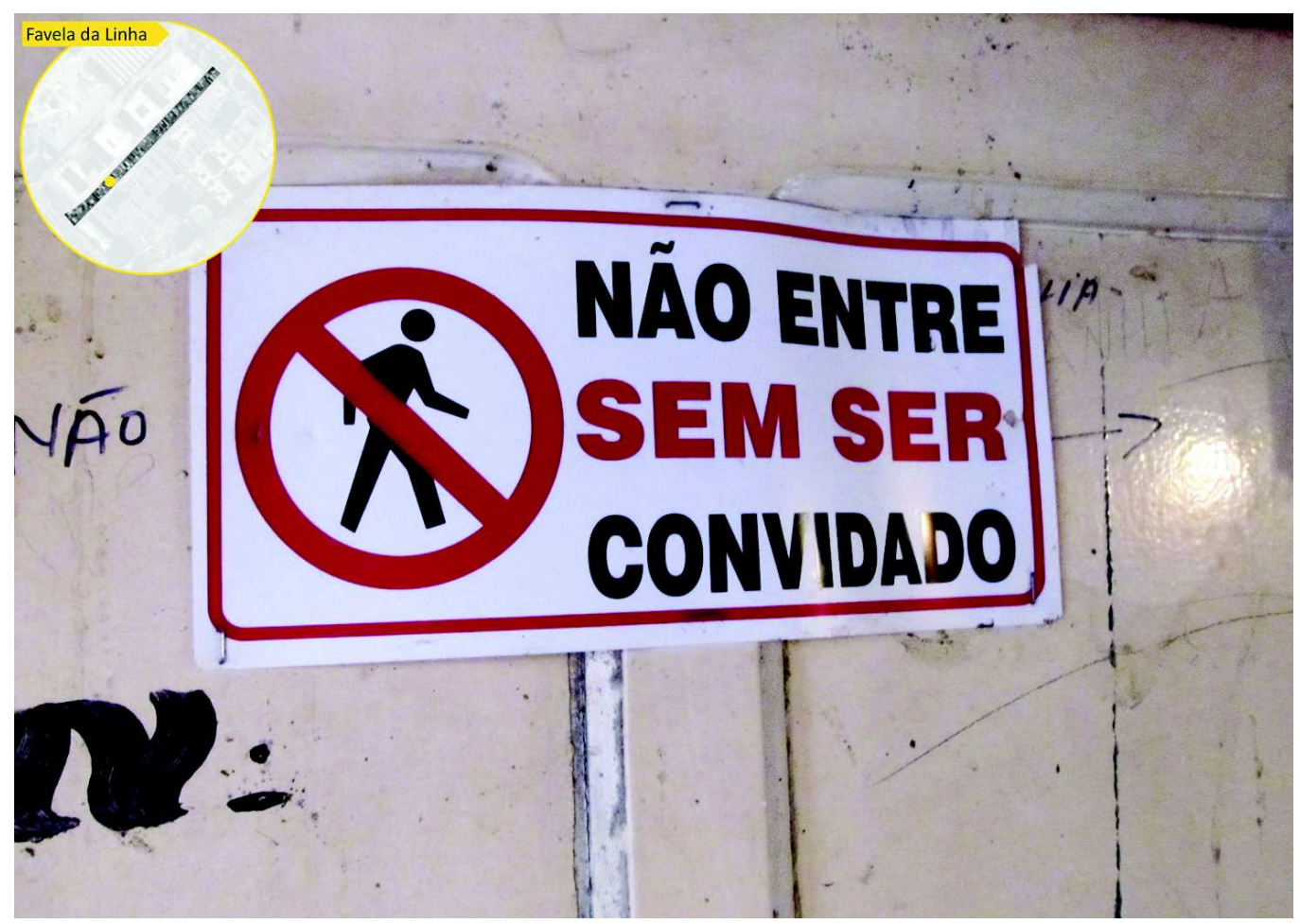

Figura 31 Delimitações claras da esfera privada na placa: 'Não entre sem ser convidado', na favela da Linha. Foto: Eduardo Pimentel Pizarro, 2012.

\section{CONSIDERAÇÕES FINAIS}

Este artigo teve como objetivo fazer uma leitura de três favelas da cidade de São Paulo a partir dos conceitos de espaço livre, espaço público e privado e espacialidades da esfera pública.

Pode-se dizer, ainda como forma de provocação e questionamento: 1) o conceito de espaços livres público e privado, em favelas, não deve se associar à propriedade fundiária legal da terra urbana em si, mas à propriedade fundiária informal e às lógicas de uso e apropriação comunitárias; 2) a interface estabelecida entre espaços públicos e privados é mais tênue e permeável nas favelas, se comparada ao restante da cidade; 3) as espacialidades da esfera pública são fundamentais para o entendimento holístico das favelas (dinâmicas urbanas, sociais, econômicas, políticas, culturais), pois abrangem a quase totalidade do território informal; 4) na favela seria possível tratar o conjunto de espaços livres privados como um efetivo sistema de espaços livres privados.

Segundo Marzulo:

Andar pelo interior de uma favela desse tipo é uma experiência sensorial radical para quem vem de espaços projetados pela racionalidade moderna. Num contexto mundial em que se debate cada vez mais a proliferação de não-lugares e dinâmicas de padronização do espaço à revelia das identidades culturais, talvez como expressão da própria crise destas, estaria no espaço periférico ou desarticulado do tecido 
urbano-metropolitano onde vivem os pobres, exatamente devido a sua formação e a pequena e apenas paliativa ação da modernidade, emergindo lugares? (MARZULO, 2005 apud KLINTOWITZ, 2008, p. 157).

Tomadas as devidas precauções para evitar romantizações exacerbadas da realidade, e partindo do que ressalta Marzulo, como seria possível pensar em absorver lições do SEL de favela para a discussão, proposição e reconstrução do sistema de espaços livres da cidade formal ou da cidade como um todo (figura 32)?

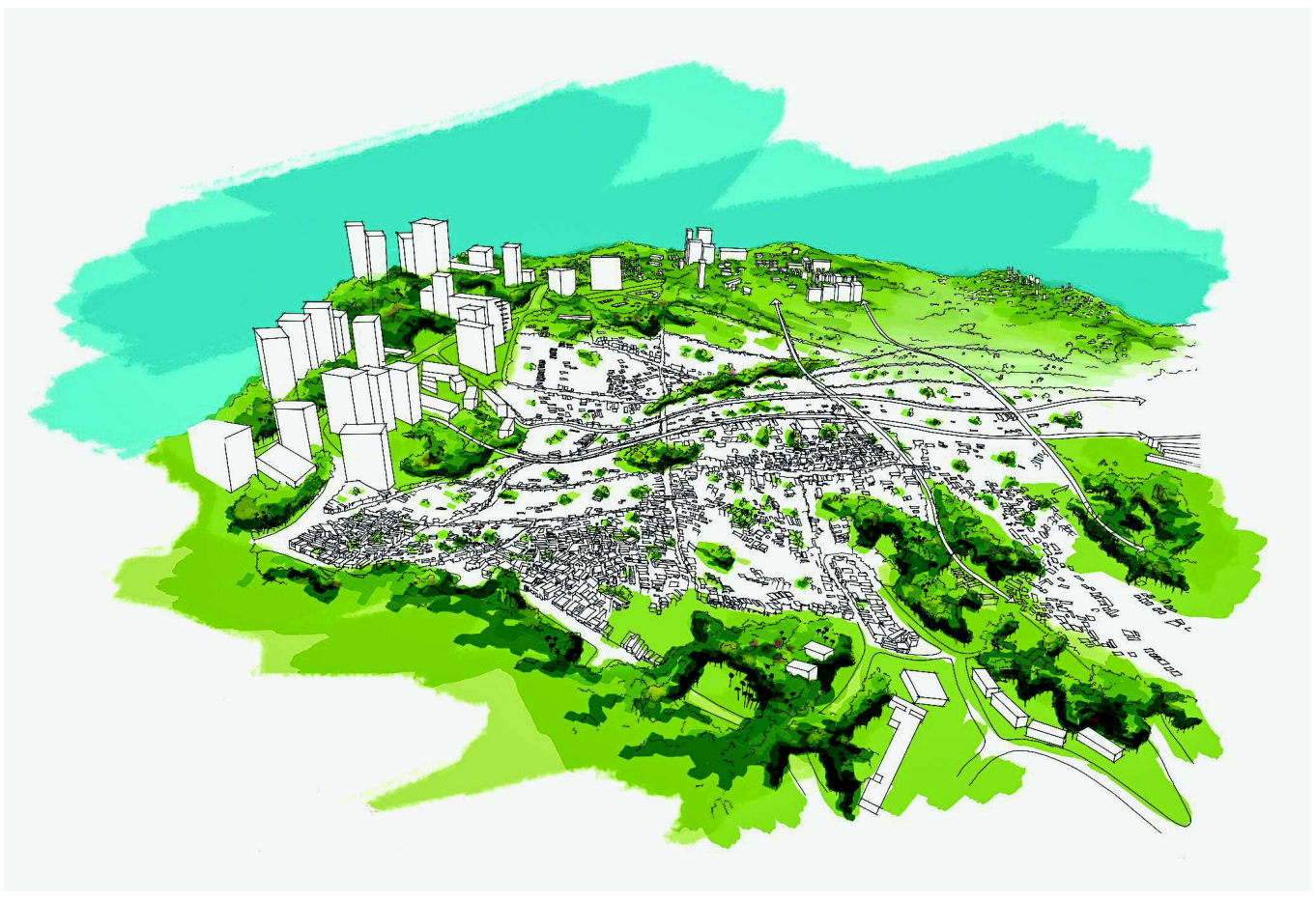

Figura 32 Possível requalificação do SEL da favela de Paraisópolis.

Desenho de Eduardo Pimentel Pizarro, 2014.

\section{REFERÊNCIAS BIBLIOGRÁFICAS}

ALENCAR, Vagner de; BELAZI, Bruna. Cidade do Paraíso: há vida na maior favela de São Paulo. São Paulo: Primavera Editorial, 2013.

ARENDT, Hannah. A condição humana. 5 ed. Tradução de Roberto Raposo. Rio de Janeiro: Forense Universitária, 1991.

BRASIL. Lei n 10.406 de 10 de janeiro de 2002. Institui o Código Civil. Disponível em: <http://www.planalto.gov. br/ccivil_03/leis/2002/L10406.htm>. Acesso em: 6 nov. 2015.

DAVIS, Mike. Planeta favela. São Paulo: Boitempo, 2007. 272 p.

GROSBAUM, Marcia. O espaço público no processo de urbanização de favelas. 2012. 189 f. Dissertação (Mestrado em Arquitetura e Urbanismo) - Faculdade de Arquitetura e Urbanismo, Universidade de São Paulo, São Paulo, 2012.

IBGE - Instituto Brasileiro de Geografia e Estatística. Censo Demográfico 2010. Aglomerados subnormais: informações territoriais. IBGE, 2010, p. 83. Disponível em: <http://biblioteca.ibge.gov.br/visualizacao/ periodicos/552/cd_2010_agsn_if.pdf > . Acesso em: 14 ago. 2013. 
INSTITUTO ACAIA. Relatório Anual 2013. Disponível em: <http://www.acaia.org.br/wp-content/uploads/2011/06/ Relatorio2013_port_BAIXA.pdf>. Acesso em: 14 jul. 2015.

KLINTOWITZ, Danielle. A (re)invenção da praça: a experiência da Rocinha e suas fronteiras. 2008. 201 f. Dissertação (Mestrado em Urbanismo) - Faculdade de Arquitetura e Urbanismo, Pontifícia Universidade Católica de Campinas, Campinas, 2008.

MAGNOLI, Miranda Maria Esmeralda Martinelli. Espaços livres e urbanização: uma introdução a aspectos da paisagem metropolitana. 1982. 116 f. Tese (Livre Docência em Arquitetura e Urbanismo) - Faculdade de Arquitetura e Urbanismo, Universidade de São Paulo, São Paulo, 1982

MARZULO, Eber Pires. Espaço dos pobres: identidade social e territorialidade na modernidade tardia. 2005. Tese (Doutorado em Planejamento Urbano e Regional) - Faculdade de Arquitetura e Urbanismo, Universidade Federal do Rio de Janeiro, Rio de Janeiro, 2005.

ONU - Organização das Nações Unidas. A ONU e os assentamentos humanos. 2000. Disponível em: <https:// nacoesunidas.org/acao/assentamentos-humanos/>. Acesso em: 10 abr. 2012.

Relatório sobre a situação da população mundial. 2011 . Divisão de Informações e Relações Externas do $\overline{\text { Fundo }}$ de População das Nações Unidas (UNFPA). Disponível em: <http://www.un.cv/files/PT-SWOP1 1 -WEB.pdf>. Acesso em: 14 ago. 2014.

PIZARRO, Eduardo Pimentel. Interstícios e interfaces urbanos como oportunidades latentes: o caso da favela de Paraisópolis, São Paulo. Dissertação (Mestrado em Arquitetura e Urbanismo) - Faculdade de Arquitetura e Urbanismo, Universidade de São Paulo, São Paulo, 2014.

QUEIROGA, Eugenio Fernandes. A megalópole e a praça: o espaço entre a razão de dominação e a razão comunicativa. 2001. 351 f. Tese (Doutorado em Arquitetura e Urbanismo) - Faculdade de Arquitetura e Urbanismo, Universidade de São Paulo, São Paulo, 2001.

Espacialidades da esfera pública na urbanização contemporânea: o caso da megalópole do Sudeste. In: MAGNOLI, Miranda Maria Esmeralda Martinelli; KAHTOUNI, Saide; TOMINAGA, Yasuko (Orgs.). Discutindo a paisagem. São Carlos: RiMa, 2006, p. 121-142.

Dimensões públicas do espaço contemporâneo: resistências e transformações de territórios, paisagens e lugares urbanos brasileiros. 2012. 284 f. Tese (Livre Docência em Arquitetura e Urbanismo) - Faculdade de Arquitetura e Urbanismo, Universidade de São Paulo, São Paulo, 2012.

ROSA, Marcos L (Ed.). Microplanning: urban creative practices. São Paulo: Editora de Cultura, 2011.

SEHAB - Secretaria de Habitação. Projetos de Urbanização, 2010.

\section{AGRADECIMENTOS}

À Fapesp (Fundação de Amparo à Pesquisa do Estado de São Paulo) pelo financiamento da pesquisa de Mestrado (em São Paulo e Londres) que deu origem a esse artigo.

A Joana Carla Soares Gonçalves, pela orientação e amizade.

Nota do editor

Submetido em: 1 set. 2015

Aprovado em: 4 mai. 2016 